
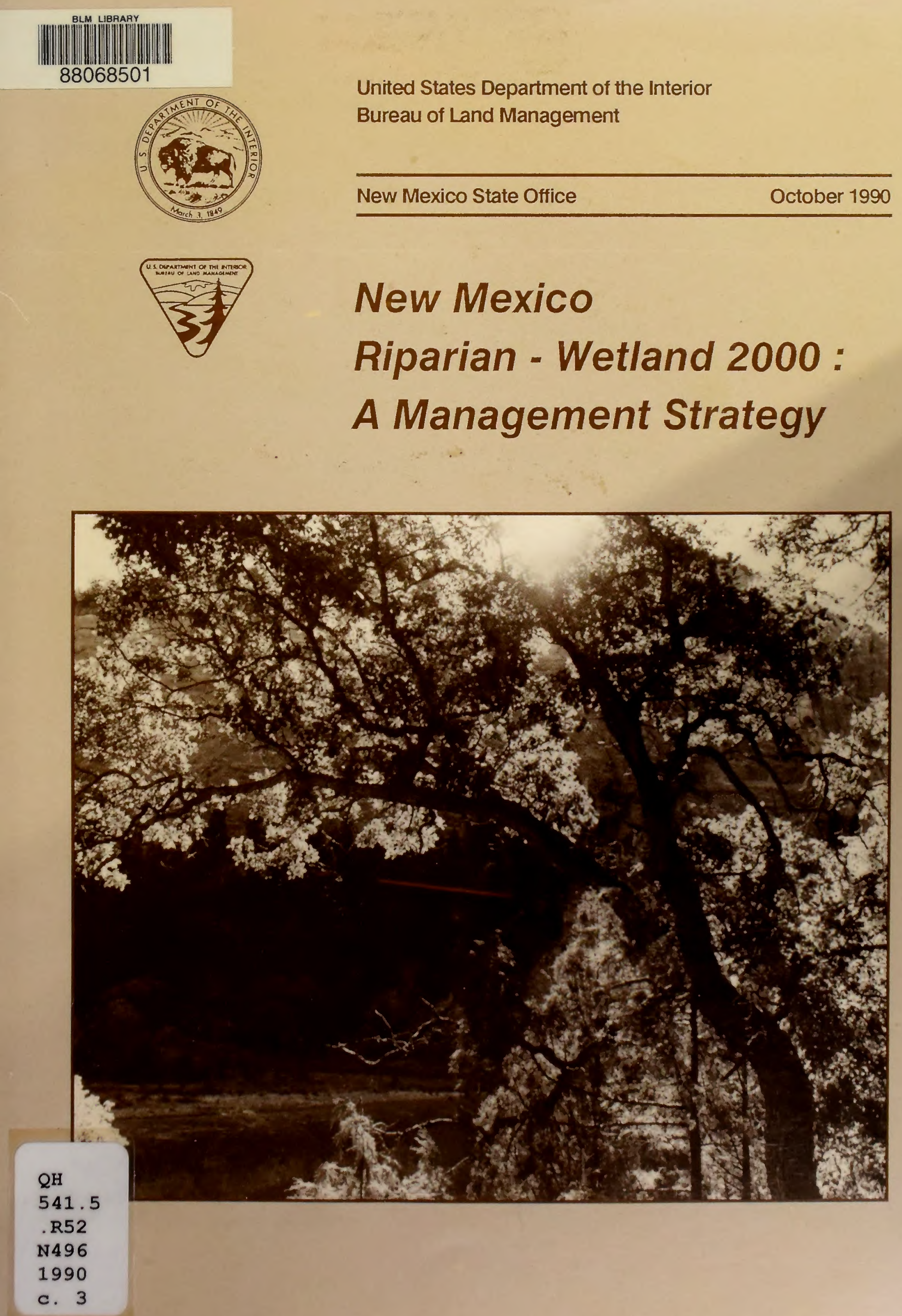
Photographs and illustrations courtesy of the New Mexico Department of Game and Fish and the Bureau of Land Management.

Riparian-wetland logo designed by the Bureau of Land Management Albuquerque District Office 


\title{
NEW MEXICO RIPARIAN-WETLAND 2000 : \\ A Management Strategy
}

\author{
U.S. Department of the Interior \\ Bureau of Land Management \\ New Mexico State Office \\ Santa Fe, New Mexico
}

October 1990 

State Director's Statement

The Bureau of Land Mangement (BLM) is responsible for the balanced management of 12.8 million acres of public lands in New Mexico which include at least 27,600 acres of streams, wetlands, and riparian corridors. Our Oklahoma City Resource Area is expected to obtain administration of up to another 90,000 acres along the Red River of Oklahoma/Texas.

These "riparian-wetland" areas, although small in size, are of critical importance to both society and the environment. These narrow arteries of life are important for plants, wild life species, soil stability, and water quality and quantity. Livestock operators utilize these areas for both livestock forage and water; most wildlife species, including endangered species, are dependent or closely associated with them; domestic, industrial, and agricultural water users divert water from them; and recreationists prefer them over other areas. All of these uses on a resource in short supply in an arid region has often resulted in overuse of these areas.

Although the BLM only manages a small percentage of existing riparian-wetland areas, we have assigned a top priority to the management of this critical resource on public lands. Care of this resource involves a watershed approach, which includes cooperation with other landowners, both public and private. Solutions must be through cooperation with all affected interests: grazing permittees, environmental, economic, and others.

The challenge is great, but the goals are achievable and the benefits are to all. The BLM is committed to effective riparian-wetland management of public lands for the long-term. This document is a major step in that direction, and although contingent on Congressional appropriations, it is designed to maintain and/or improve ecological conditions on public lands and establish BLM policy and direction to BLM field offices.

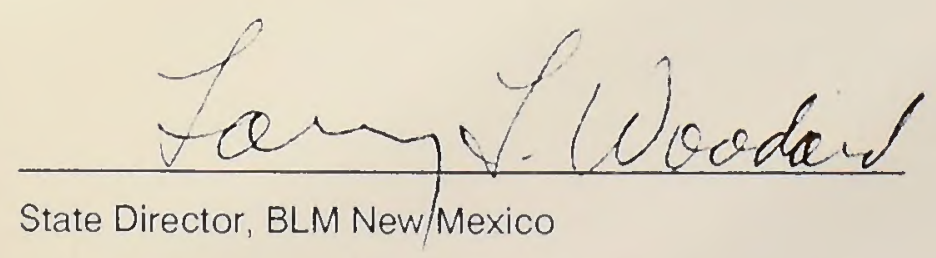

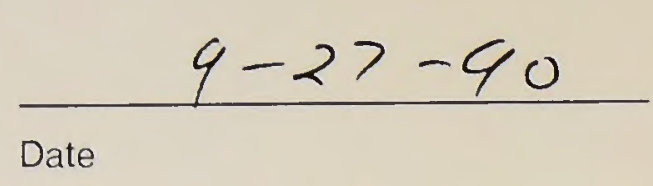





\section{Table of Contents}

INTRODUCTION

PURPOSE AND NEED

ACCOMPLISHMENTS

PLANNED ACTIONS AND ESTIMATED COSTS - FY90-2000

\section{Maps}

Public Lands Administered by the BLM New Mexico State Office

\section{Tables}

Summary of Land Use Plans and Activity Plans with Riparian-Wetland Area Objectives (FY87-89) _ . . 5 Summary of Riparian-Wetland Area Inventory Accomplishments (FY87-89) . . . . . . . . . . . . 7 Summary of Riparian-Wetland Area Monitoring Accomplishments (FY87-89) _ . . . . . . . . . . . . 8 Summary of Riparian-Wetland Area Project Development (FY87-89) . . . . . . . . . . . . . . . 9 Summary of Riparian-Wetland Showcase Areas, by District and Resource Area . . . . . . . . . . 10

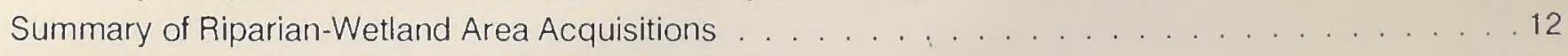
Summary of Projected Staffing Needs, by Discipline . . . . . . . . . . . . . . . . . . . 18 Summary of Riparian-Wetland Area Workload and Budget (FY87-2000) . . . . . . . . . . . 25

\section{Appendices}

A - Legislation, Executive Orders, Policy, and Guidance

B - National and New Mexico Resource Program Goals

\section{Glossary of Terms}





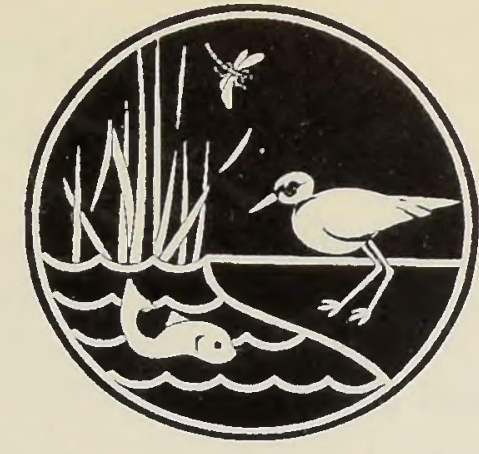

NEW MEXICO

RIPARIAN-WETI AND 2000 :

\section{A Management Strategy}

\section{Introduction}

Where watercourses snake their way through this arid land, the green zones along the water channels provide an oasis for an amazing diversity of life. These green areas along rivers, streams, springs, bogs, wet meadows, lakes, and ponds are called riparianwetland areas. Wetlands include the aquatic zones of marshes, cienegas, streams, and springs. Riparian areas, wetlands, and other water areas are grouped together and called riparian-wetland areas in this document. Today, more than ever before, there are ever-increasing demands on water, a most limited, yet most valuable, resource in the Southwest.

Riparian-wetland areas comprise 0.21 percent of the 12.9 million acres of public lands in New Mexico, yet these unique areas are among the most important ecosystems in the Southwest. Productive habitats, they provide water, food, cover, and shade for animals and birds and a special niche for species not seen in the surrounding arid landscape. Riparian-wetland areas control sediment, help to recharge groundwater, and absorb and reduce the energy of floodwater. These areas are crucial to the integrity of entire watersheds. Livestock have historically utilized them, and increasingly, they are providing people a focal point for recreation activities.

For the Bureau of Land Management (BLM), steward of our Federal public land estate, riparian-wetland areas have taken on new meanings and importance. Increased multiple-use demands on these important riparian-wetland areas have raised public expectations that we intensify our management efforts throughout the State. On January 22, 1987, BLM Director Robert Burford adopted a Bureau policy directed at achieving a healthy and productive ecological condition for public land riparian-wetland areas. More recently, BLM Director Cy Jamison has made riparian-wetland area management a top priority.

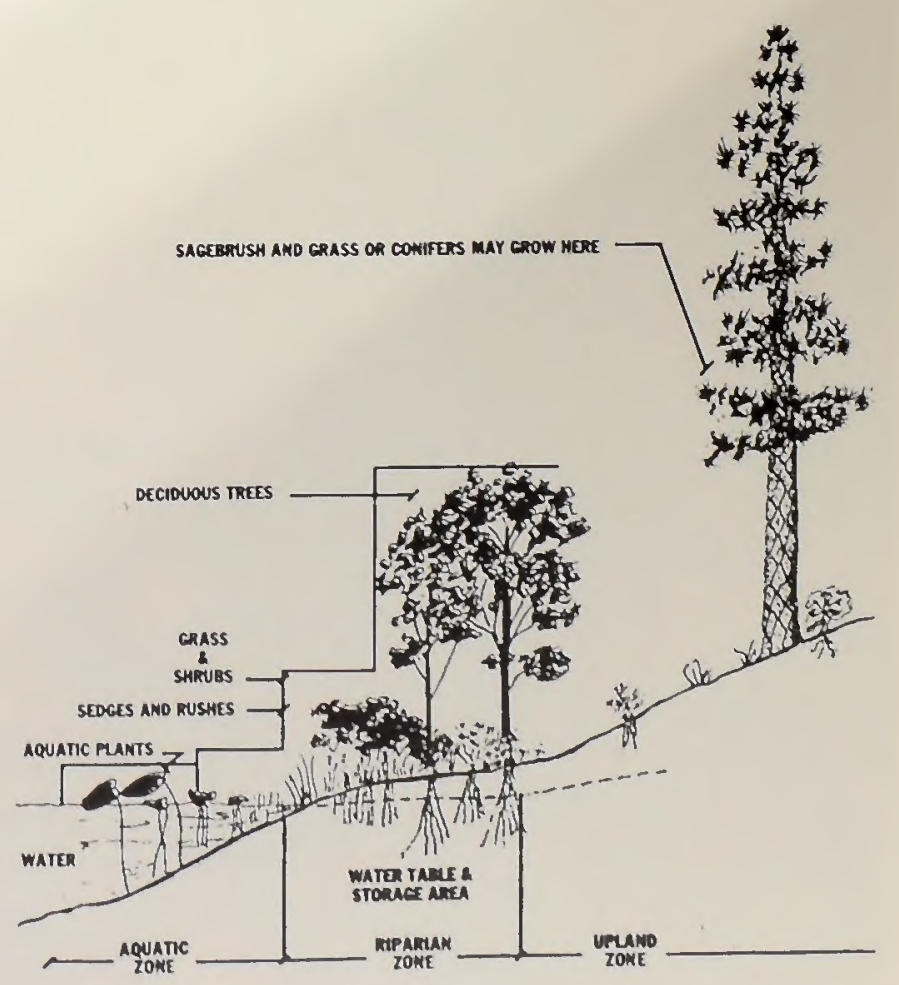

Riparian-Wetland Areas are Identified by the Presence of Vegetation that Requires Large Amounts of Free or Unbound Water 
Several laws and policies deal with wetlands, floodplains, and related areas which are encompassed by the term riparian. (See Appendix A.)

Partnerships, with public organizations and cooperating agencies alike, characterize BLM's stepped up activities. Sparked by the Isaak Walton League, our Bluewater Riparian-Wetland Area Enhancement Project in the spring of 1989 saw a dozen agencies and 300 volunteers build fences, water gaps, and trails; plant willows; create rock structures for fish; and clean up litter along Bluewater Creek in central New Mexico. Riparian-wetland area management is an exciting endeavor, one in which people can get involved. Many opportunities exist to include volunteers in restoration efforts and project maintenance.
The challenge is there: riparian-wetland areas have the highest levels of species richness in the Southwest. From high mountain valleys to undulating prairies, varying vegetation types line 250 miles of wetlands and perennial streams, occupying 27,600 acres of public lands in New Mexico. Also, the Tulsa District, which is administered by the BLM New Mexico State Office (NMSO), may contain an additional 116 miles of riparian-wetland habitats on the Red River pending cadastral survey. An estimated 90,000 acres of riparian habitat occur on this section of the Red River.

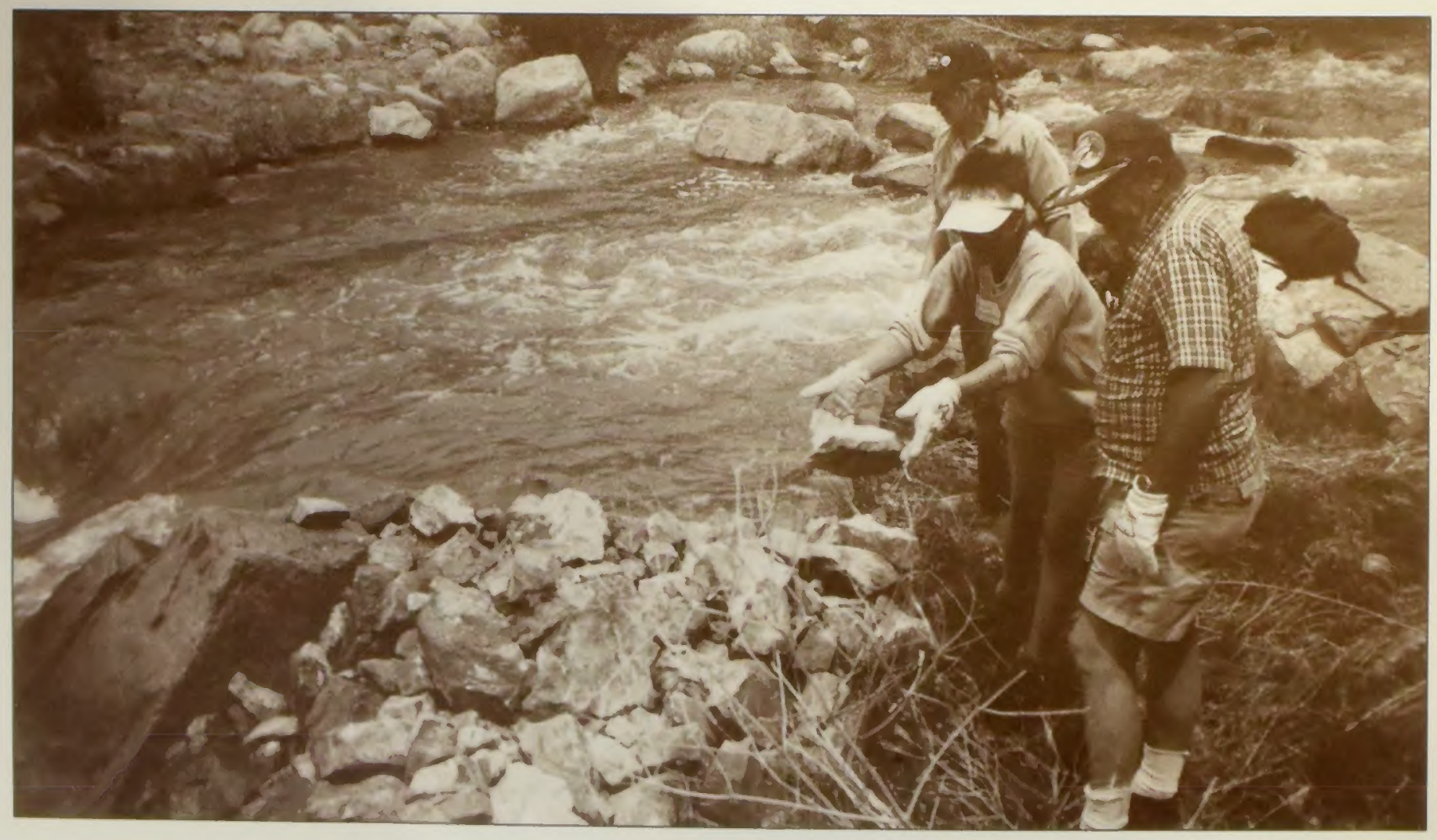

Volunteers Help Plant Willows on Bluewater Creek 


\section{Purpose and Need}

The purpose of this document is to identify and consolidate planning decisions as well as determine the needs for future planning development, as related to riparian-wetland area resource management. This document serves as a bridge between BLM's land use plans and the activity plans. In order to accomplish this, the document pulls together all relevant planning decisions to identify coordination opportunities for activity planning. In this manner, it transcends traditional resource program area boundaries. In addition the document identifies issues not addressed in land use plans that are nevertheless essential for consideration in activity planning to meet legal obligations and avoid leaving out a resource component that should be included in the management prescriptions Lastly, it serves as a vehicle to convey information to the public and land users on BLM's Riparian-Wetland Management Program.

Land use decisions contained in resource management plans (RMP's) represent the Bureau's intention to take specific actions on the ground. Riparian-Wetland Management 2000 is intended to be used as a Bureau policy to implement management activities in a coherent manner, promote efficient utilization of human and financial resources, and improve communication in the activity planning process. It provides a unifying set of objectives, summarizes management guidelines within which management prescriptions can be developed, and lays out standard operating procedures for activities in riparian-wetland areas.

The next level of planning following RMP's are activity plans. These are site-specific plans which detail more specifically how land use decisions will be implemented. BLM activity plans are completed for differing purposes, including habitat management plans (HMP's) for wildlife, allotment management plans (AMP's) for grazing, coordinated resource management plans (CRMP's) for multiple resources, and areas of critical environmental concern (ACEC's) for special management areas (SMA's).

Riparian-Wetiand Management 2000 challenges us to expand the focus of activity planning from the interests of any one resource subactivity to the piece of ground for which management prescriptions are developed to meet multiple-use management objectives. By helping to change the focus to the piece of ground, we hope to encourage authorship of, as well as responsibility for, management prescriptions among all resource subactivities, interest groups, and cooperating agencies and encourage an interdisciplinary approach to on-the-ground management.

Once management prescriptions are in place, monitoring and maintenance of riparian-wetland area conditions are important parts of BLM's Riparian-Wetland Management Program. Monitoring tools include the use of permanent photo points, vegetation transects, and the cyclic collection of large scale aerial photography and other techniques used to measure broader changes in communities and riparian-wetland zones. Maintenance work includes fence repair, signing, and structural maintenance of improvements.

Benefits of riparian-wetland area management are many and diverse, ranging from improvement in water quality and quantity to sediment retention, reduced flooding effects, better vegetative cover, improved fishery and wildlife habitat, and more forage production to name only a few. 
Public Lands Administered by the BLM New Mexico State Office

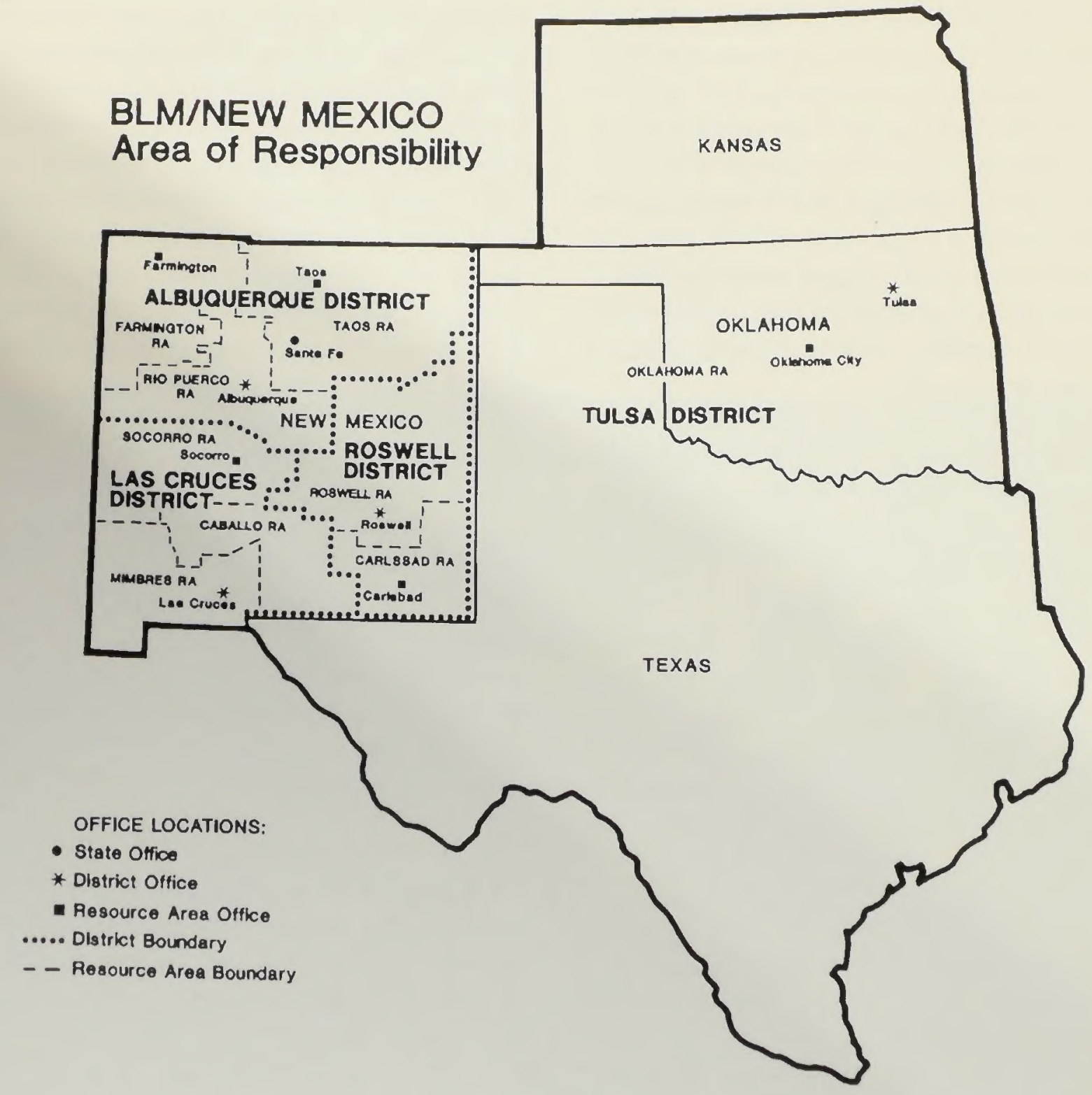




\section{Accomplishments}

Riparian-wetland area accomplishments are tied to various Bureau land use and activity plans. Through Fiscal Year 1989 (FY89), there were seven RMP's and four management framework plans (MFP's is the term used for early BLM land use plans). Nineteen sitespecific riparian related plans have been developed to date on public lands. Existing activity plans include six HMP's, three ACEC's, four CRMP's, two river management plans, one AMP, one cooperative plan, one cooperative management plan (CMP), and one watershed rehabilitation plan, which are directed either totally or in part toward achieving riparian-wet- land area management goals and objectives. (See table below for specific land use and activity plans.)

Many Bureau planning efforts have addressed riparian-wetland area management concerns. The programmatic oil and gas environmental assessments (EA's) in the Roswell and Farmington Resource Areas (RA's) during the early 1970's contained several specific provisions for wetland protection. The Roswell RA's interest in Lee Lake Overflow in 1975 and the Mimbres RA's work on the San Simon Cienega in 1976 and in the Lower Gila Box in 1985 demonstrate early concern for these important areas.

Summary of Land Use Plans and Activity Plans with Riparian-Wetland Area Objectives (FY87-89)

\section{DISTRICT/RESOURCE AREA}

Albuquerque District

Farmington RA

Taos RA

Rio Puerco RA

Rio Puerco RMP

Las Cruces District

Mimbres RA

Socorro RA

Tulsa District

Oklahoma RA

Roswell District

Carlsbad RA

Roswell RA
LAND USE PLAN

Farmington RMP

Taos RMP

Southern Rio Grande MFP Gila MFP

Socorro RMP

None

Carlsbad RMP

East Chaves MFP

Roswell MFP Analysis (MFPA)/EIS

Fort Stanton MFPA/EIS
ACTIVITY PLAN

San Juan Basin River HMP

Rio Grande River Management Plan

Chama River Interim Management Plan

Bluewater ACEC Plan

El Malpais HMP

San Luis Mesa Raptor ACEC Plan

San Isidro Watershed Rehabilitation Plan

Lower Gila Box CRMP

Organ Mountain CRMP

San Simon Cienega CMP

Lake Holloman Coop Plan

Rio Grande HMP

None

Carlsbad Riparian HMP

Tecolote Peak CRMP

Jumping Springs CRMP

Pecos River Canyon ACEC

Overflow Wetlands HMP

Fort Stanton HMP

Terrel AMP 
An interesting study can be used to illustrate the effects of riparian-wetland area protection and enhancement. The Rio Bonito Creek Demonstration Project in the Roswell RA was established in 1983 with construction of two protective exclosures to determine aquatic and vegetative response. Photopoint and monitoring studies completed in 1988 revealed impressive increases in plant and animal diversity; bank stabilization was evident with dramatic changes in stream bank vegetation; pioneer plants were evident on gravel bars; aquatic plants were common; and the exotic salt cedars died as they were submerged by rising water levels. This is visible testimony of ecosystem response to riparian-wetland area management. This project has since become BLM New Mexico's riparian-wetland showcase area for developing and demonstrating riparian management techniques

Not all of the success stories demonstrate highly visible changes in vegetation. In fact, one of our finest examples of stream management is not the result of a single cottonwood pole being planted, fence being built, or cow being moved. This success has been demonstrated over the past 6 years by improving flow

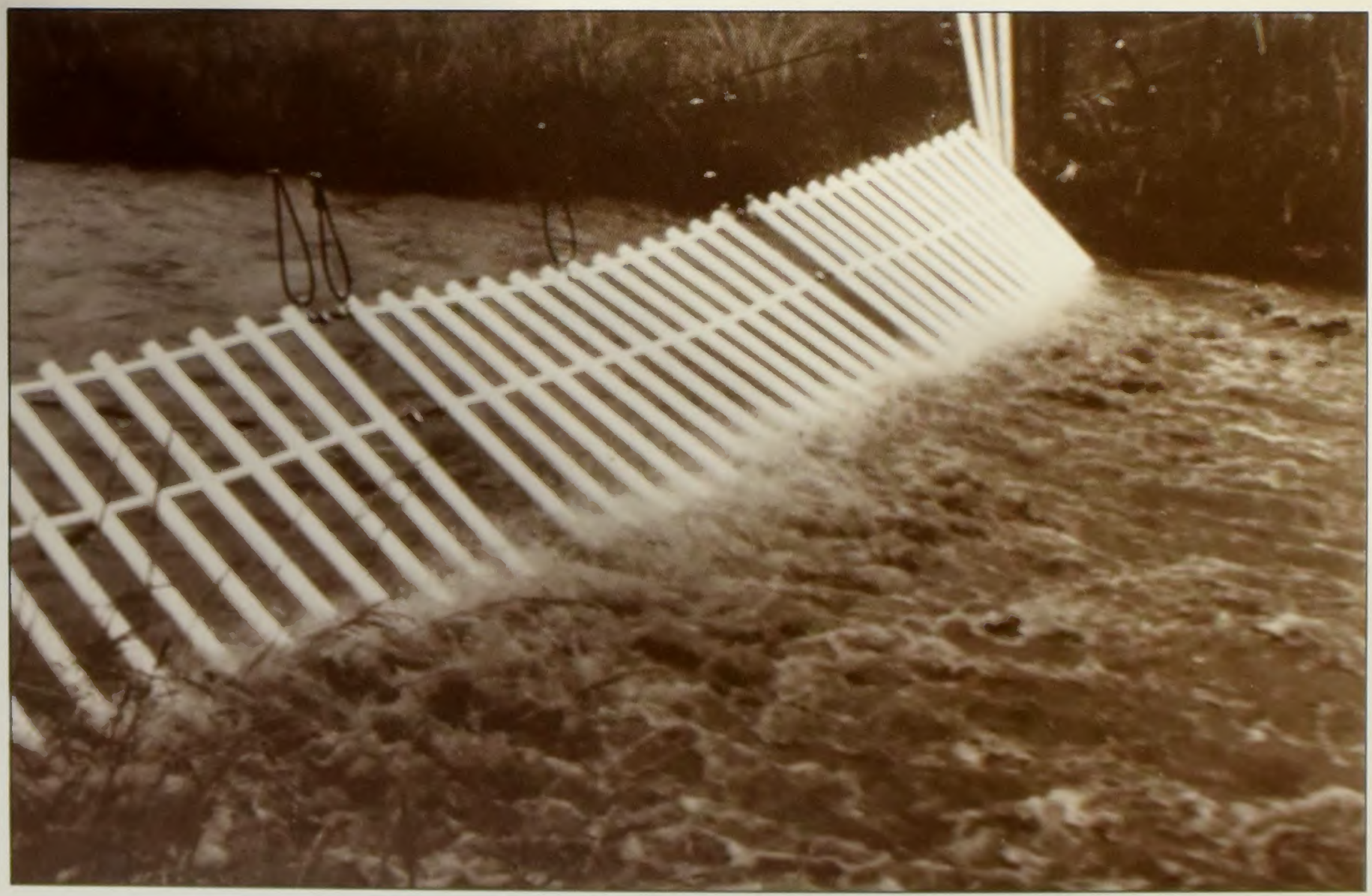

Swinging PVC Pipe Fence 
management on the Rio Chama below El Vado Dam. This single action enhanced a put-and-take rainbow trout fishery to a "blue ribbon" rainbow and brown trout fishery. Prior to management efforts, the previous flow regimes had virtually eliminated brown trout reproduction. Since then, trout productivity has dramatically improved this public recreation resource. This accomplishment required the investment of time to coordinate the efforts of five Federal agencies, three State agencies, municipal water owners, and several private interest groups.
Cumulative accomplishments for the State through FY89 include the following initiatives.

- Approximately 13,200 acres inventoried along 142 miles of stream.

- Twenty-seven monitoring studies

- Forty-one projects completed.

- Riparian-wetland showcase areas established in each RA.

- Twenty-one miles of riparian areas are being acquired (by 1991).

(See the following tables for specific accomplishments.)

Summary of Riparian-Welland Area Inventory Accomplishments (FY87-89)

\section{DISTRICT/RESOURCE AREA}

Albuquerque District

Farmington RA

Taos RA

Rio Puerco RA

District Total

\section{Las Cruces District}

Mimbres RA

Caballo RA

Socorro RA

District Total

Tulsa District

Oklahoma RA

District Total

Roswell District

Carlsbad RA

Roswell RA

District Total

STATE TOTAL
PROGRAM

NO. OF ACRES/MILES

Wildlife
Wildlife
Wildlife

$746 / 5$

$1.080 / 19$

$1,617 / 57$

$3,443 / 81$

Range

Wildlife

Wildlife

Wildlife

Wildlife

Wildlife

2,000

2,000 .

Wildlife

Wildlife

$500 / 11$

$1635 / 29$

2135/40

$13,200 / 142$

Inventory methods include the Stream Habitat Survey Method; electro shocking for T/E fish; cover, composition, crown density, diameter at breast height (dbh), vigor, and structure measurements; comparison to (USFWS) wetland maps; the BLM Integrated Habitat Inventory and Classification System (IHICS); and District riparian-wetland area evaluation forms. 


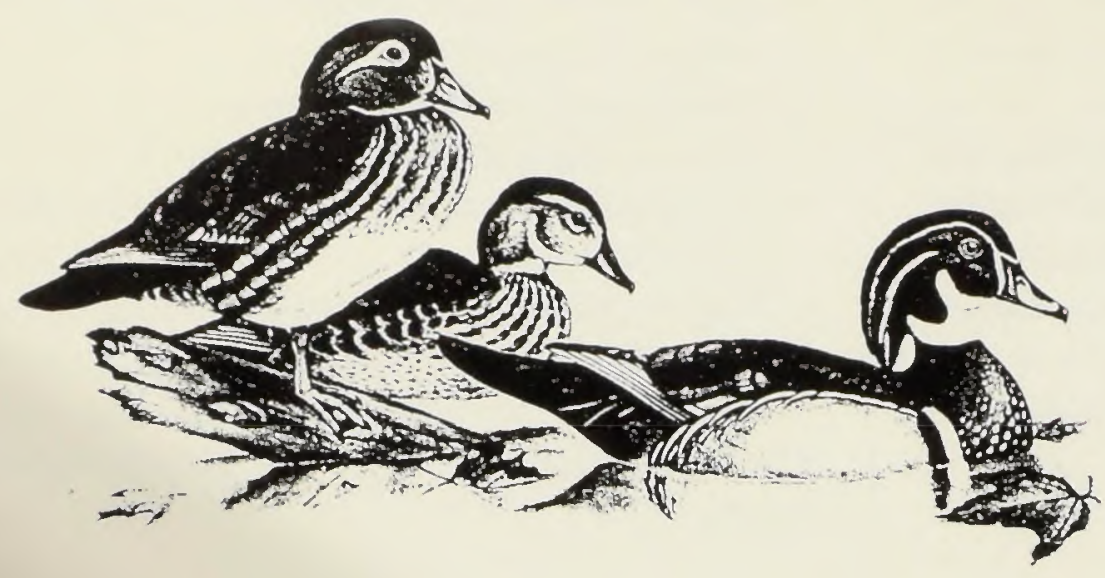

Many Waterfowl Species are

Common to Riparian-Wetland Areas

Summary of Riparian-Wetland Area Monitoring Accomplishments (FY87-89)

\section{DISTRICT/RESOURCE AREA}

\section{Albuquerque District}

Taos RA

Rio Puerco RA

District Total

\section{Las Cruces District}

Mimbres RA

Caballo RA

Socorro RA

District Total

\section{Roswell District}

Carlsbad RA

Roswell RA

District Total
PROGRAM

NO. OF STUDIES

\section{Range}

3

Watershed

Wildlife

Wildlife

3

6

Wildlife

Range

Wildlife

Wildlife

Wildlife

Wildlife

\section{1}

6

7

27

STATE TOTAL

Monitoring methods include photopoints; United States Geological Survey (USGS) stream flow gauges; riparianwetland area stand analysis transects; avian transects; water quality measurements; and range utilization, trend, and condition. 
Summary of Riparian-Wetland Area Project Development (FY87-89)

\begin{tabular}{|c|c|c|c|}
\hline DISTRICT/RESOURCE AREA & $\begin{array}{l}\text { NO. OF } \\
\text { PROJECTS }\end{array}$ & FY & TYPE \\
\hline \multicolumn{4}{|l|}{ Albuquerque District } \\
\hline \multirow[t]{4}{*}{ Farmington RA } & 2 & 87 & Fencing \\
\hline & 2 & 87 & Cottonwood pole plantings \\
\hline & 2 & 88 & Fencing \\
\hline & 1 & 89 & Watershed improvement \\
\hline \multirow[t]{2}{*}{ Taos RA } & 1 & 87 & Demonstration \\
\hline & 1 & 88 & Water gaps \\
\hline \multirow[t]{2}{*}{ Rio Puerco } & 5 & 88,89 & Exclosures, Plantings, Spring development \\
\hline & 1 & 88 & Spring development \\
\hline District Total & 15 & & \\
\hline \multicolumn{4}{|l|}{ Las Cruces District } \\
\hline \multirow[t]{5}{*}{ Mimbres RA } & 1 & 86 & Cottonwood pole plantings \\
\hline & 1 & 87 & Cottonwood pole plantings \\
\hline & 1 & 88 & Cottonwood pole plantings \\
\hline & 1 & 88 & Spring exclosure \\
\hline & 4 & 89 & Fencing, Well, Plantings, Salt cedar control \\
\hline \multirow[t]{2}{*}{ Socorro RA } & 1 & 87 & Spring development, Exclosure \\
\hline & 1 & 88,89 & Spring development, Exclosure, Fencing \\
\hline District Total & 10 & & \\
\hline \multicolumn{4}{|l|}{ Tulsa District } \\
\hline Oklahoma RA & 2 & 89 & Signing, Traffic control \\
\hline District Total & 2 & & \\
\hline \multicolumn{4}{|l|}{ Roswell District } \\
\hline Carlsbad RA & 5 & 89 & Exclosures, Salt cedar control \\
\hline \multirow[t]{7}{*}{ Roswell RA } & 3 & 83 & Exclosures \\
\hline & 1 & 86 & Water gap \\
\hline & 1 & 87 & Water gap \\
\hline & 1 & 87 & Seeding \\
\hline & 1 & 87 & Demonstration, Cottonwood pole plantings \\
\hline & 1 & 87 & Exclosure \\
\hline & 1 & 88 & Cottonwood pole plantings \\
\hline District Total & 14 & & \\
\hline STATE TOTAL & 41 & & \\
\hline
\end{tabular}




\section{Summary of Riparian-Wetland Showcase Areas, by District and Resource Area}

Beginning in FY86, riparian-wetland showcase areas, previously called riparian demonstration projects, were established on selected BLM tracts. The purpose is to demonstrate the capability of these areas to respond to various resource management prescriptions. Following is a summary of showcase areas, by District and RA.

\section{Albuquerque District}

Ojo Caliente (Taos RA) - Initiated in 1986 to provide riparian-wetland area vegetation restoration by temporary livestock exclusion. Cottonwood poles were planted in FY87 but did not survive; however, natural regeneration of cottonwoods and willows is occurring. Funding programs: range and wildlife.

San Juan River HMP, Trucha Rosilla (Farmington RA) - Initiated in FY86. This small tract is similar to other isolated tracts on the San Juan River under this HMP. Accomplishments include cadastral survey, recreational development, signing, and monitoring with photo documentation. Future plans include plantings, salt cedar removal, and elimination of grazing. Funding program: wildlife.

Bluewater Canyon ACEC (Rio Puerco RA) - Plans include fisheries management, recreational development, livestock protection, and water quality analysis. The 1989 Bluewater Riparian Project saw over a dozen agencies and groups cooperate in planting thousands of willows and coltonwoods, building trails, fences, and instream structure, and picking up trash. Funding program: wildlife.

\section{Las Cruces District}

Max Adams Allotment (Mimbres RA) - Initiated in 1985, this project has included use of volunteers (Boy Scouts) for riparian-wetland area plantings, small livestock exclosures, and wire check dams. Future plans include additional check dams, plantings, and use of volunteers. Funding program: wildlife.

Lower Gila Box CRMP (Mimbres RA) - The Gila River is an extremely important riparian-wetland ecosystem important for endangered species, recreation, watershed, and wilderness values. It is a multi-program initiative with a management plan written in FY86. Animal surveys have been done, as well as plantings. Additional livestock fencing and land acquisition is planned. Funding programs: range, wildlife, and recreation.

Percha Creek (Caballo RA) - Draft HMP prescribes livestock management to allow cottonwood and willow regeneration with minimal fencing. Public access improvement and signing will be accomplished.

\section{$\overline{\text { Roswell District }}$}

Fort Stanton (Roswell RA) - This is the New Mexico Riparian-Wetland Showcase Area. It was nominated and accepted as a result of its resources which include the Rio Bonito and Rio Salado, representative of streams in the piñon-juniper zone. This 24,515-acre former military reservation also offers unique administrative opportunities. It was, until recently, used by New Mexico State University as a wildlife, livestock, and range research station. Management plans for the area include implementation of the Fort Stanton Riparian-Wetland HMP; use for riparian-wetland area management training; development and testing of riparian inventory procedures; and 
conducting grazing management strategies, designed to enhance riparian ecological conditions. The Rio Bonito dedication ceremony was held on April 21, 1990. The event was a volunteer project, involving approximately 350 persons, in conjunction with Earth Day 1990. Projects completed include two riparian-wetland area livestock exclosures, tree plantings, trash removal, juniper removal, and stream bank stabilization.

Owl Spring (Carlsbad RA) - This project includes removal of salt cedar surrounding the spring with chemical treatment and prescribed fire. These plots are monitored with large-scale aerial photography. In addition, 3 miles of OWl Draw is being intensively managed (fencing, water developments, prescribed fires, and monitoring) to improve grassland/riparian-wetland community and reduce mesquite and salt cedar communities. Funding program: wildlife.

\section{Tulsa District}

Red River, Jefferson County, Oklahoma (Oklahoma RA) - This riparian-wetland showcase area consists of a public lands signing effort and restricting vehicular access to the 2,000 acres of public lands in this 6-mile stretch of the Red River floodplain. Photo points have been used and signs are being monitored for visibility and vandalism. Future activities will be governed by the Oklahoma RMP scheduled for completion in FY93. Activities could include prescribed fires, parking lot construction, and CRMP or HMP's involving Oklahoma State agencies in the management of these public lands.

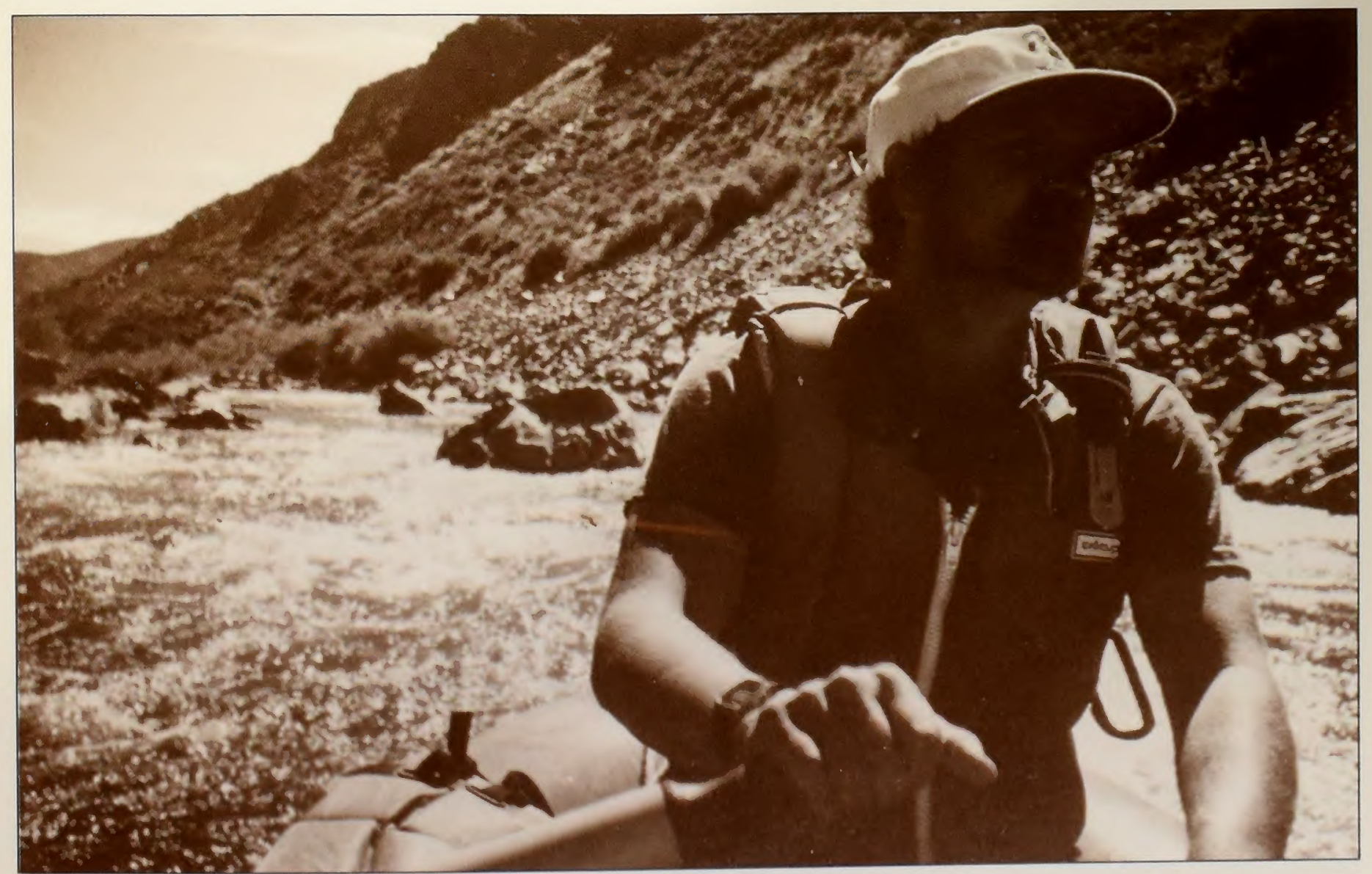

The Rio Chama and Rio Grande Offer River Rafiing Experiences 


\section{Summary of Riparian-Wetland Area Acquisitions}

The following summaries depict recent and planned riparian-wetland area acquisitions by BLM in New Mexico. A total of 21 miles of perennial streams and 9,507 acres will be available for public use as a result of this effort.

\begin{tabular}{|c|c|c|}
\hline & Non-Federal & Year Completed \\
\hline Stream Miles & Acres Acquired & \\
\hline
\end{tabular}

\section{Bolack Exchange}

1

917

1982

This exchange resulted in BLM acquiring prime riparian-weltand and raptor nesting habitat along the San Juan River in northwest New Mexico, in exchange for 6,545 acres of upland public lands. This river frontage is immediately downstream from a "blue ribbon" trout fishery.

\section{Rio Grande Tracts \\ $1 / 2$ \\ 74 \\ 1987-89}

Three small tracts, including Manby Hot Springs on the upper Rio Grande near Taos, New Mexico. These private inholdings have been acquired by purchase agreement and provide an additional 1/4-mile of river area for public use, including fishing, floating, and outdoor recreation.

Gila Lower Box

70

1988

Two private tracts acquired by direct purchase in the heart of the Lower Gila River surrounded by public lands. Values include occurrence of the Federal-listed spidedace minnow, recreational fishing, hiking, river floating, and scenic and wildlife viewing. Other small private inholdings exist in this area.

\section{Ice Canyon}

3

2,814

1988

This acquisition resulted in the BLM acquiring land which contains habitat for several threatened and endangered plants and animals, potential desert bighorn range, prime raptor areas, and one of the few riparian-wetland areas found in the Organ Mountains. The BLM has converted the original ranch property into a visitor's center and has developed picnic areas and hiking trails.

\section{Black River}

3 48

1990

Portions of the tract were acquired by The Nature Conservancy (TNC). It includes a water right with important riparian-wetland habitat in an arid environment; recreation potential; occurrence of the ferruginous hawk, a candidate for Federal listing; and the gypsum milkvetch, a State-listed plant species.

\section{Rio Grande Gorge State Park}

$11 / 2$

1,341

1990

This park, renamed the Orilla Verde BLM Recreation Area, is situated in northcentral New Mexico in the heart of the upper Rio Grande. The park is being conveyed back to BLM under agreement with the State of New Mexico. It includes opportunities for camping, picnicking, trout fishing, rafting, and other outdoor recreation.

\section{Abercrombie}

1

179

1991

This private tract provides access to the scenic Bluewater ACEC. As well as being a trout fishery, the Bluewater ACEC provides riparian-wetland research and environmental educational values and hiking and scenic viewing opportunities. The tract is being acquired by TNC for conveyance to BLM via ongoing land exchange actions. It is being considered for a Research Natural Area (RNA) designation by BLM. 


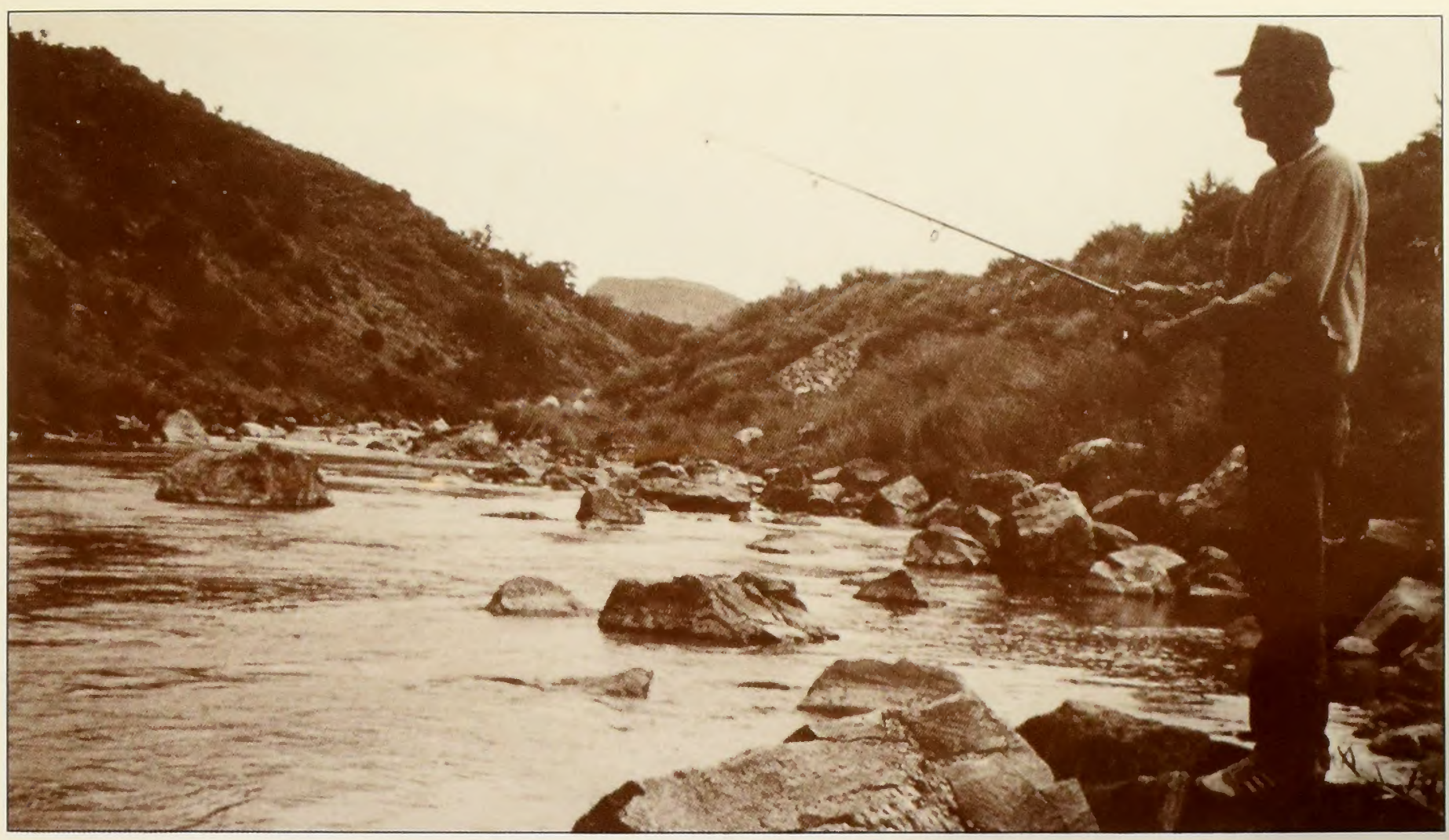

Fishing on the Rio Grande Gorge

Rio Chama 3

1,020

1992

This action involves five private inholdings to the Rio Chama Wild and Scenic River in northcentral New Mexico. This section of the Rio Chama is a scenic gorge, popular for whitewater rafting, trout fishing, and outdoor recreation. Acquisition through exchange or purchase is under consideration.

\section{Apache Box}

$1 / 2$

800

1990

A remote riparian-wetland area, a small stream, is in southwest New Mexico on the Arizona/New Mexico line. This tract has been acquired by TNC for conveyance to BLM via exchange action.

Overflow Wetlands

804

1990

Prime wetlands along the Pecos River in southeast New Mexico provide habitat for waterfowl, sandhill cranes, snow geese, and shorebirds. It is also inhabited by the Pecos pupfish, a candidate for Federal listing, and is potential habitat for the Greenthroat darter and Mexican tetra, which are State-endangered species. High recreational interest for wildlife viewing and hunting. Acquisition is occurring by exchange or purchase via Land and Water Conservation Fund.

\section{Delaware River \\ 7 \\ 1,000 \\ 1991}

This prime area includes a water right. Located in southeast New Mexico, values include habitat for the ferruginous hawk; the Texas hornshell (mussel), a candidate for Federal listing; the Mexican tetra, a State-endangered fish; recreational fishing and floating; and important riparian-wetland habitat. This proposal is for acquisition by TNC for conveyance to BLM via an ongoing exchange action. 


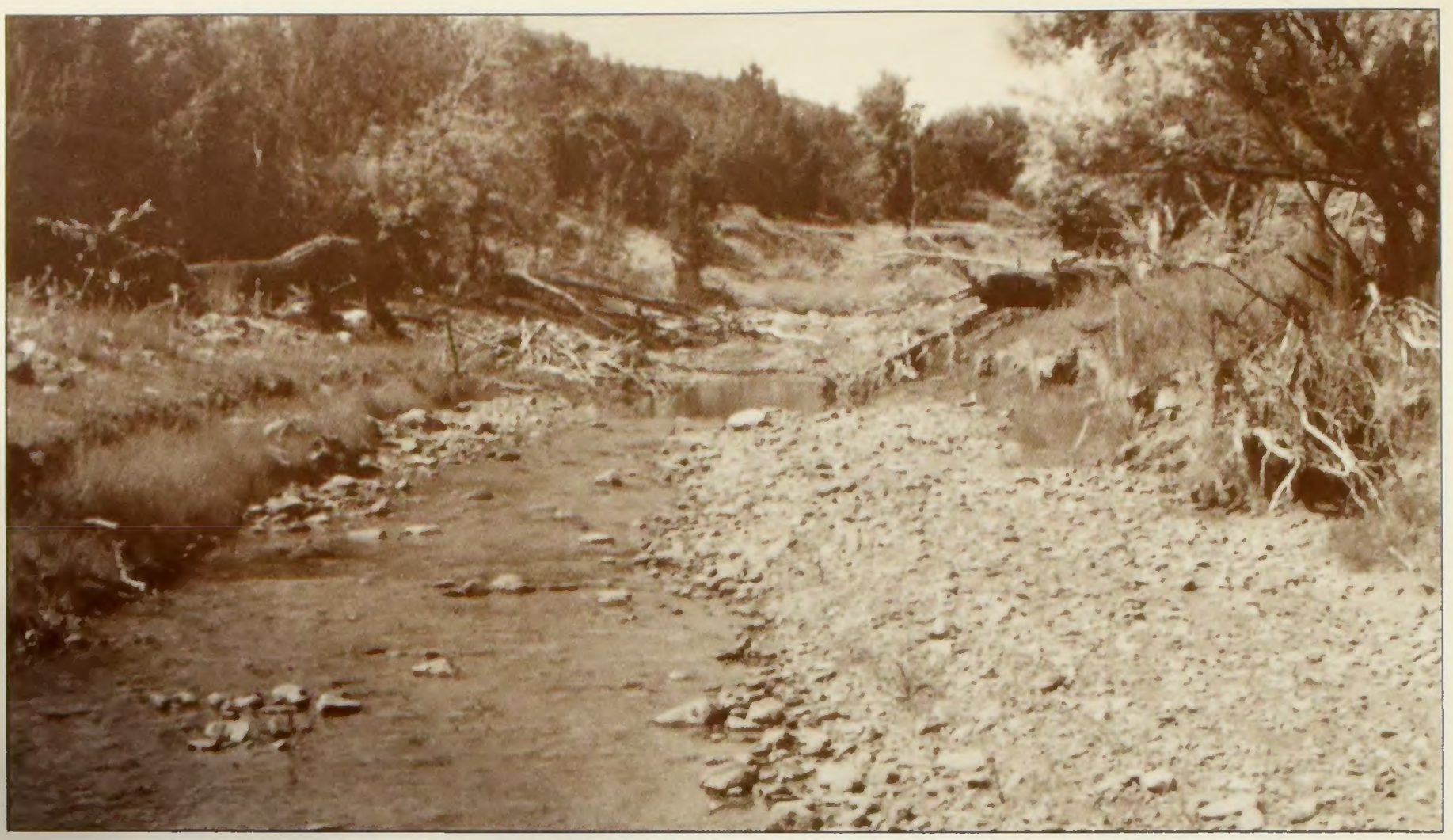

Fort Stanton Riparian-Wetland Area Before Livestock Exclosure

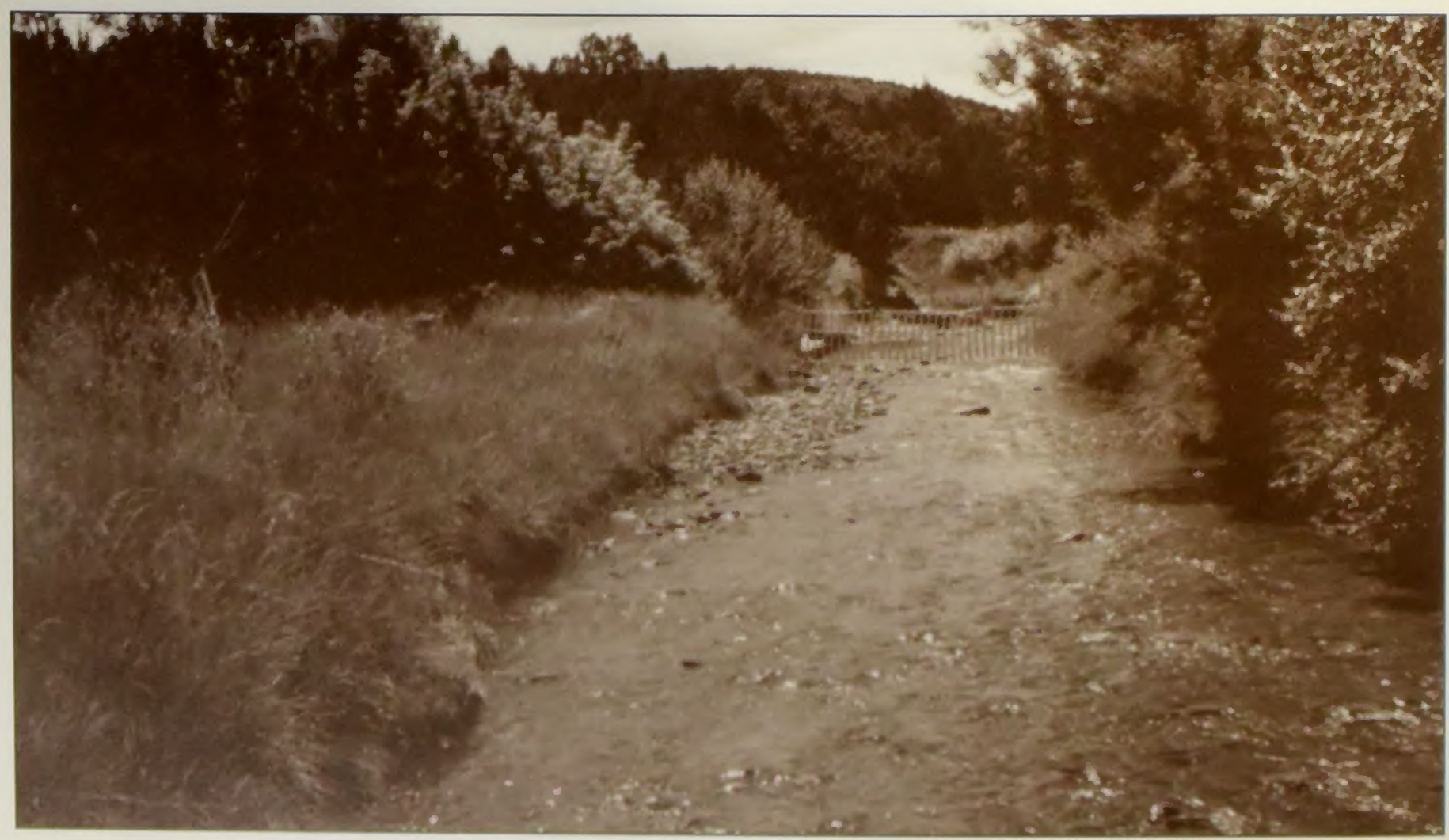




\section{Specific Program Goals and Objectives}

Following are the Bureau's specific goals and objec tives for attainment by the year 2000. (See Appendix B for National and State program goals established in furtherance of BLM's Riparian-Wetland Management Program.)

Goal: Restore, maintain, and improve riparian-wetland area conditions on public lands in New Mexico.

Objectives:

- Establishing riparian-wetland area management objectives via the RMP process and the development of activity plans

- Amending, as necessary, existing planning documents to include riparian-wetland area management objectives.

- Using all available funding sources for project development and maintenance, including Sikes Act, Challenge Cost Share, volunteers, and appropriate Bureau base funding subactivities.

- Ensuring all riparian-wetland area projects and maintenance are tied to planning objectives.

- Including upland restoration and rehabilitation of watersheds in riparian-wetland area management prescriptions.

- Encouraging interagency and interdisciplinary CMP's to develop and achieve management objectives on a watershed basis, wherever possible.

- Emphasizing proper land use practices in lieu of structural developments as remedies for poor watershed conditions.

- Using acquisitions or land ownership exchanges as riparian-wetland area management tools. Retain riparian-wetland tracts of significant value or trans- fer to other agencies which will maintain riparianwetland area values.

- Establishing specialist positions within each RA to coordinate planning, project development, and maintenance.

Goal: Ensure that land use management is achieving riparian-wetland area management objectives

Objectives:

- Developing site-specific, interdisciplinary management objectives for riparian-wetland areas using inventory and site-potential data.

- Developing "New Mexico Riparian-Wetland Area Inventory Minimum Standards."

- Completing an extensive and intensive Statewide inventory to make a broad assessment of riparianwetland area resource extent, condition, and management needs.

- Using extensive and intensive inventory data as a baseline for riparian-wetland area monitoring. Baseline data will include nonconsumptive and consumptive water needs, as well as flow characteristics of the area.

- Completing aerial photo coverage for 250 miles of perennial streams or high priority riparian-wetland areas and establishing permanent photo monitoring stations.

- Developing monitoring studies based upon sitespecific management objectives; periodically evaluating studies to track and document progress in achieving management objectives; and including monitoring plans in site-specific activity plans to ensure objectives are being met. 
- Developing ecological site descriptions for selected riparian-wetland areas to ensure that management objectives are within resource capabilities based on soils, vegetation, and hydrologic potential of the site.

- Utilizing the Bureau automated Land Information System (LIS) and associated subsystems to store, retrieve, and manipulate data.

- Developing intensive inventory procedures for soil, ecological condition, and instream flow information needs.

- Monitoring the New Mexico Riparian-Wetland Management 2000, reporting accomplishments, and updating.

Goal: Develop a public Riparian-Wetland Outreach Program to provide information and education opportunities.

\section{Objectives:}

- Implementing outreach programs at State Office (SO), District Office (DO), and RA Office levels to demonstrate the significance and success of the Bureau's Riparian-Wetland Habitat Management Program by:

- Providing information on successful grazing management approaches.

- Promoting and conducting field tours in conjunction with demonstration projects.

- Videos.

- Producing and distributing pamphlets.

- Developing public presentations.

- Presenting environmental education modules in public schools.

- Utilizing BLM New Mexico riparian-wetland habitat logo to provide a "look" for promoting the RiparianWetland Management Program. This will serve to increase public awareness of riparian-wetland habitat values (brown insert in Sunday paper) and can be used on awards, volunteer t-shirts, hats, signs, publications, memoranda, or budget requests dealing with riparian-wetland habitat management.

- Supporting the establishment of a New Mexico Riparian-Wetland Area Council or coalition to promote cooperation in riparian-wetland area enhancement.

- Improving management effectiveness through the development and maintenance of active cooperation with interested groups.

- Promoting development of memoranda of understanding (MOU's) or cooperative management agreements (CMA's) with private interest groups, educational institutions, or volunteers that invest time or money in support of BLM riparian-wetland area management actions.

- Expanding gift catalog opportunities for riparianwetland habitat management, including acquisition or access needs.

- Enhancing BLM cooperative relationships with other Federal, State, or local governments and private parties through frequent consultation and coordination on jointly managed stream reaches.

- Cooperating with the U.S. Soil Conservation (SCS) Plant Materials Center to develop native plants for restoration of riparian-wetland areas, where needed.

- Sharing information, management objectives, and monitoring results.

- Identifying opportunities for involving organizations, such as the Wool Growers, New Mexico Cattle Growers American Mining Congress, forest/ timber associations, and others to provide for improved understanding and management of riparian-wetland habitat management. 
- Continuing to demonstrate Bureau expertise and capabilities to effectively manage riparian-wetland habitat in a multiple-use forum.

- Expanding riparian-wetland demonstration areas and other management initiatives to include upland watershed areas, which are key to proper riparianwetland area management.

- Initiating successful grazing management strategies and presenting results at professional society meetings and sportsman's club meetings as well as to other interested groups.

- Establishing interdisciplinary teams at each organizational level to develop and implement riparian-wetland area management plans. values. Of the 19 western states, only New Mexico has no provision to generally protect instream flows for the benefit of riparian-wetland areas.

\section{Objectives:}

- Supporting instream flow legislation and determining instream flow requirements that would meet BLM management objectives.

Goal: Train specialists and managers in riparianwetland area management concepts and practices.

\section{Objectives:}

- Establishing a Riparian-Wetland Training Program that would provide managers and resource specialists the opportunity to develop expertise in riparian-

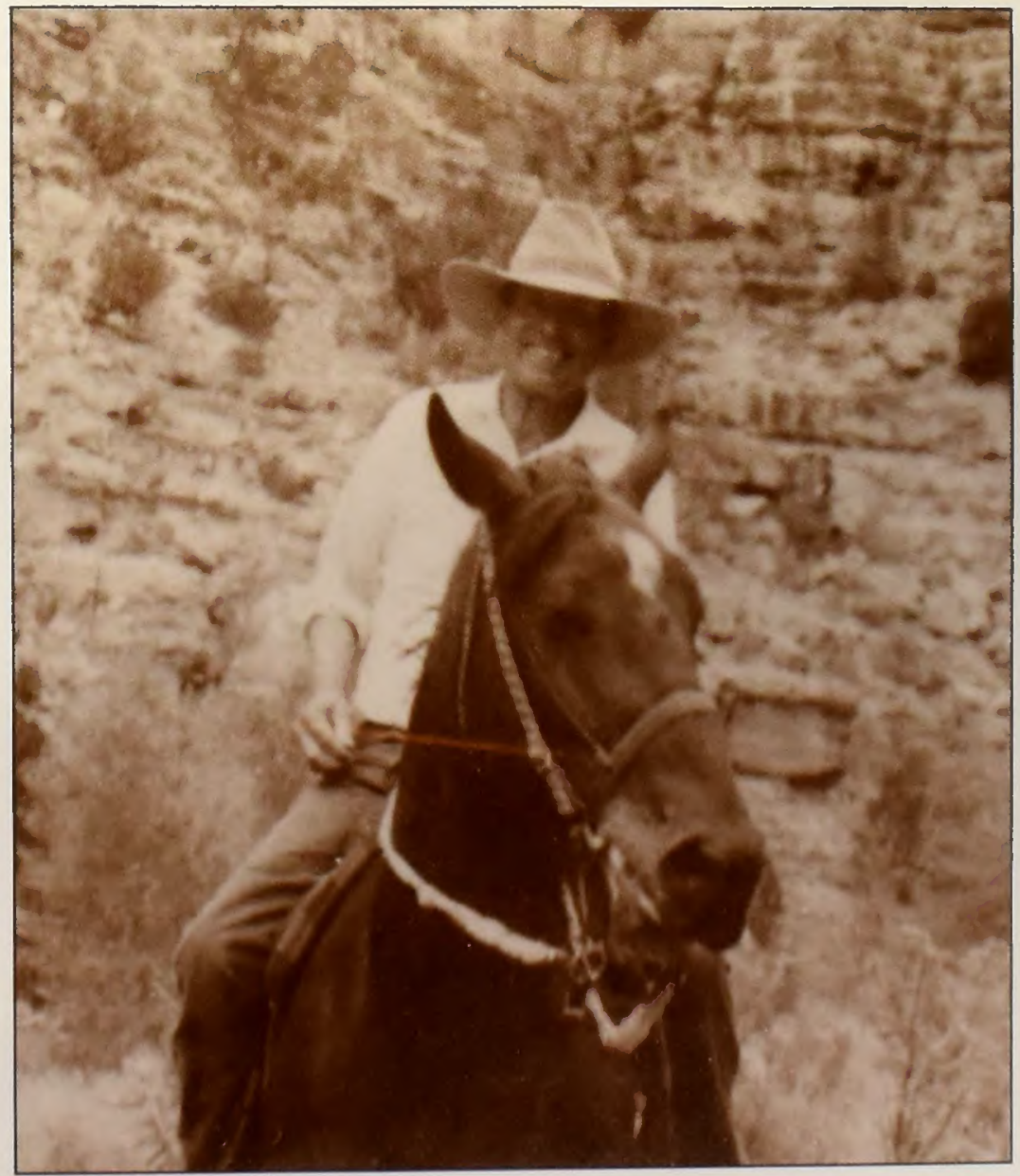
wetland area management. This training should include both technical and managerial perspectives. 


\section{Planned Actions and Estimated Costs - FY90-2000}

The FY90-2000 planned actions are conservative estimates based on information on hand at this writing. Staffing requirements (14 additional positions) are those positions needed over and above current levels. Approximately seven of these positions would be needed in the first 5 years, and the additional seven in the last 5 years. Under current funding levels, only about 20 percent of the projected workload can be accomplished. An increase of 4.9 million dollars in the BLM New Mexico base budget ( $\$ 480,000$ per year) is required to fully implement this strategic plan.
Range conservationists are urgently needed to assist in determining ecological site potential and desired plant communities, design and implement grazing prescriptions and practices, supervise livestock use, and monitor effects of management. Fish and wildlife biologists are needed to assess habitat requirements and assist in designing and implementing management practices, as well as in monitoring. Hydrologists and soil scientists are needed to analyze soil-water interactions. Engineers are also needed to help in all aspects of riparian-wetland restoration and management. (See table below for a summary of anticipated staffing needs.)

Summary of Projected Staffing Needs, by Discipline

Discipline

No. of Positions

Range

Wildlife

Fishery

Soils

Hydrology

Engineering

TOTAL
5

3

1

1

2

2

14 


\section{Planning}

STATEWIDE - 6 AMP's with riparian-wetland area management objectives

TAOS RA - Rio Chama HMP, Wild Rivers HMP, Warm Springs SMA

ROSWELL RA - RMP, Overflow HMP

OKLAHOMA RA - begin Oklahoma RMP (data collection Red River)

MIMBRES RA - implement San Simon CMP

\section{Inventory and Monitoring}

Inventory

STATEWIDE - initiate large scale aerial photography contract

ROSWELL RA - 185 acres/4.6 miles

RIO PUERCO RA - 200 acres/12 miles

TAOS RA - 500 acres $/ 30$ miles

FARMINGTON RA - 186 acres $/ 0.5$ miles

OKLAHOMA RA - 90,000 acres/116 miles (extensive inventory)

TOTAL - 91,071 acres/163.1 miles

\section{Monitoring}

CARLSBAD RA - 3 units

RIO PUERCO RA - 1 unit

CABALLO RA - 1 unit

MIMBRES RA - 2 units

TOTAL - 7 units

\section{Project Development and Maintenance}

Development

CARLSBAD RA - exclosure, fences, burn, chemical control, erosion control structure, planting - 6 units
ROSWELL RA - Rio Bonito Volunteer Project: plantings, vegetation control, stream structures - 7 units RIO PUERCO RA - exclosure - 1 unit

FARMINGTON RA - fencing - 1 unit, plantings

2 units

SOCORRO RA - fence reservoirs and springs, develop springs - 3 units

TAOS RA - pooling structures, fence trash catchers -3 units

MIMBRES RA - prescribed burn, plantings, exclosures, salt cedar control - 5 units, pipeline

- 3 miles

TOTAL - 31 units

Maintenance

MIMBRES RA - fences, exclosures, water developments - 4 units

CARLSBAD RA - fences, control structures, plantings, water developments - 4 units

ROSWELL RA - fencing - 1 unit

RIO PUERCO RA - exclosures - 6 units, spring development - 1 unit

FARMINGTON RA - fencing - 1 unit

TAOS RA - water gaps in demonstration area - 1 unit OKLAHOMA RA - signs, vehicle barriers - 2 units TOTAL - 20 units

\section{Riparian-Wetland Area Acquisitions}

CARLSBAD RA - Black River

TAOS RA - Rio Grande Gorge State Park

MIMBRES RA - Apache Box

ROSWELL RA - Overflow Wetlands

* Actual units completed may differ from those planned. 


\section{FY91 Planned Actions}

\section{Planning}

ALL OFFICES - emphasize riparian-wetland area management in grazing AMP's, determine AMP's needed - 5 units

ALBUQUERQUE DO - complete the Albuquerque District Riparian- Wetland Program Strategy

OKLAHOMA RA - initiate Oklahoma RMP (includes Red River riparian-wetland area)

CARLSBAD RA - Upper Black River CRMP

TOTAL ACTIVITY PLANS - 6 units

\section{Inventory and Monitoring}

\section{Inventory}

TAOS RA - 400 acres/15 miles ROSWELL RA - 83 acres/ 1.9 miles CARLSBAD RA - 50 acres/ 10 miles OKLAHOMA RA - complete extensive inventory RIO PUERCO RA - 200 acres/12 miles TOTAL - 733 acres $/ 38.9$ miles

\section{Monitoring}

CABALLO RA - 1 unit RIO PUERCO RA - 1 unit MIMBRES RA - 1 unit TOTAL - 3 units

\section{Project Development and Maintenance}

Development

CARLSBAD RA - exclosures, burns, chemical control, erosion control structures, planting - 6 units ROSWELL RA - prescribed burn, stream structures -3 units

RIO PUERCO RA - exclosures, tree plantings -3 units

FARMINGTON RA - fencing - 1 unit SOCORRO RA - fence reservoirs and springs, develop springs - 4 units

TAOS RA - spring development - 1 unit MIMBRES RA - exclosures, cottonwood pole planting, prescribed burn, brush control, erosion control -5 units

TOTAL - 23 units

\section{Maintenance}

CARLSBAD RA - fences, control structures, plantings, water developments - 6 units

ROSWELL RA - tree plantings - 2 units

RIO PUERCO RA - exclosures - 6 units, spring developments - 1 unit

FARMINGTON RA - fencing - 1 unit

TAOS RA - spring development - 1 unit, pooling structures - 2 units

OKLAHOMA RA - signs, barriers - 2 units

MIMBRES RA - fences, water developments, plantings - 3 units

TOTAL - 24 units 


\section{FY92 Planned Actions}

\section{Planning}

ALL OFFICES - grazing AMP's - 10 units

TAOS RA - San Antonio-Pot Mountain HMP, San

Antonio SMA - 2 units

RIO PUERCO RA - Upper Rio Puerco HMP - 1 unit CABALLO RA - Lake Holloman HMP - 1 unit

OKLAHOMA RA - continue Oklahoma RMP

TOTAL ACTIVITY PLANS - 14 units

Inventory and Monitoring

Inventory

ALL OFFICES - begin intensive riparian-wetland inventories

TAOS RA - 300 acres $/ 10$ miles

CARLSBAD RA - 50 acres/ 10 miles

RIO PUERCO - 200 acres/12 miles

ROSWELL RA - 185 acres/4.6 miles

TOTAL - 735 acres $/ 36.6$ miles

\section{Monitoring}

MIMBRES RA - 2 units

CABALLO RA - 1 unit

RIO PUERCO RA - 1 unit

TAOS RA - Rio Chama Instream Flow Study - 1 unit

TOTAL - 5 units

\section{Project Development and Maintenance}

Development

CARLSBAD RA - exclosure, fence, erosion control structures, plantings - 6 units

ROSWELL RA - plantings, stream and watershed projects - 4 units

RIO PUERCO RA - exclosures - 4 units

FARMINGTON RA - fencing - 1 unit

SOCORRO RA - fence reservoirs and springs, develop springs - 4 units

TAOS RA - plantings - 1 unit

MIMBRES RA - fences, plantings, erosion structures

-3 units

TOTAL - 23 units

Maintenance

CARLSBAD RA - fencing, control structures, plantings, water developments - 5 units

ROSWELL RA - water gaps - 1 unit

RIO PUERCO RA - exclosures - 6 units, spring developments - 1 unit

FARMINGTON RA - fencing - 1 unit

TAOS RA - spring development - 1 unit, pooling structures - 2 units

OKLAHOMA RA - signs and vehicular barriers

-2 units

MIMBRES RA - fences, water developments, plantings -4 units

TOTAL - 23 units

\section{Riparian-Wetland Area Acquisitions}

TAOS RA - Rio Chama inholdings 


\section{FY93 Planned Actions}

\section{Planning}

ALL OFFICES - grazing AMP's - 10 units

RIO PUERCO RA - James Canyon ACEC, Ojo del

Espiritu Santo HMP - 2 units

OKLAHOMA RA - complete Oklahoma RMP (Red

River riparian- wetland area)

TOTAL ACTIVITY PLANS - 12 units

\section{Inventory and Monitoring}

Inventory

TAOS RA - 300 acres/ 6 miles

CARLSBAD RA - 50 acres/10 miles

OKLAHOMA RA - begin Red River inventory

RIO PUERCO RA - 200 acres/12 miles

TOTAL - 550 acres/28 miles

\section{Monitoring}

CABALLO RA - 1 unit

RIO PUERCO RA - 1 unit

MIMBRES RA - 2 units

TOTAL - 4 units

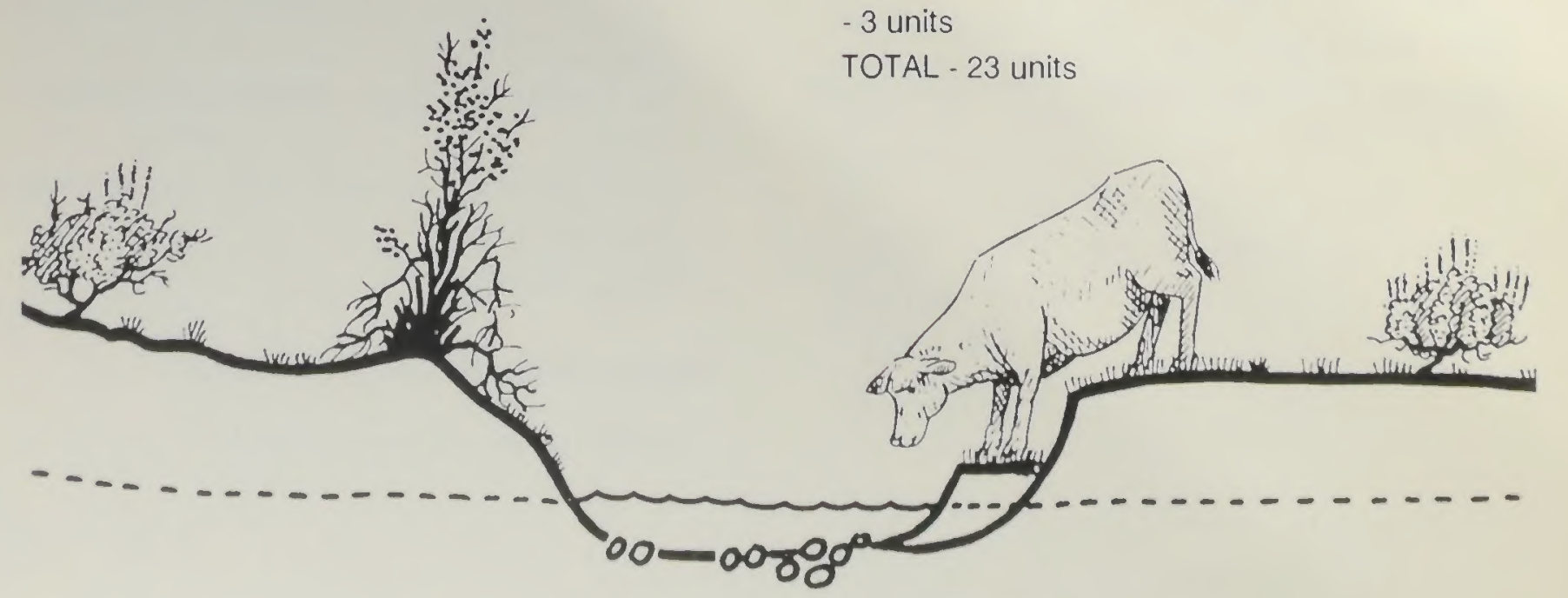

\section{Project Development and Maintenance}

Development

CARLSBAD RA - fencing, burns, erosion control structures, plantings - 4 units

FARMINGTON RA - fencing - 1 unit

SOCORRO RA - fencing reservoirs and springs, develop springs - 3 units

MIMBRES RA - prescribed burn, erosion control

-2 units

ROSWELL RA - prescribed burn, stabilization structure, exclosure -3 units

TOTAL - 13 units

\section{Maintenance}

CARLSBAD RA - fencing, erosion control structures, plantings, water developments - 5 units

ROSWELL RA - sign maintenance - 5 units

RIO PUERCO RA - exclosures - 6 units, spring development - 1 unit

FARMINGTON RA - fencing - 1 unit

OKLAHOMA RA - signs, vehicular barriers - 2 units MIMBRES RA - fences, erosion control, plantings -3 units

TOTAL - 23 units 
Planning

ALL OFFICES - grazing AMP's - 10 units

OKLAHOMA RA - Red River CRMP - 1 unit

TAOS RA - Santa Cruz HMP, Riparian Aquatic SMA

-1 unit

CABALLO RA - Sierra Co. Riparian-Wetland HMP

-1 unit

TOTAL ACTIVITY PLANS - 14 units

Inventory and Monitoring

Inventory

TAOS RA - 250 acres $/ 4$ miles

CARLSBAD RA - 50 acres/10 miles

RIO PUERCO RA - 125 acres/8 miles

TOTAL - 425 acres/22 miles

\section{Monitoring}

ROSWELL RA - 1 unit

CABALLO RA - 1 unit

OKLAHOMA RA - 1 unit

RIO PUERCO RA - 1 unit

MIMBRES RA - 2 unit

TOTAL - 6 units
Project Development and Maintenance

Development

CARLSBAD RA - exclosures, fences, chemical control, erosion control structures, plantings - 3 units ROSWELL RA - watershed projects - 2 units

RIO PUERCO RA - exclosures - 6 units

FARMINGTON RA - fencing - 1 unit

OKLAHOMA RA - begin Red River CRMP implementation

MIMBRES RA - brush control, erosion control

-2 units

TOTAL - 14 units

\section{Maintenance}

CARLSBAD RA - fencing, control structures, plantings, water developments - 5 units

RIO PUERCO RA - exclosures - 6 units, spring development - 1 unit

FARMINGTON RA - fencing - 1 unit

OKLAHOMARA - signs and vehicle barriers - 2 units MIMBRES RA - fences, erosion control, plantings -3 units

TOTAL -18 units

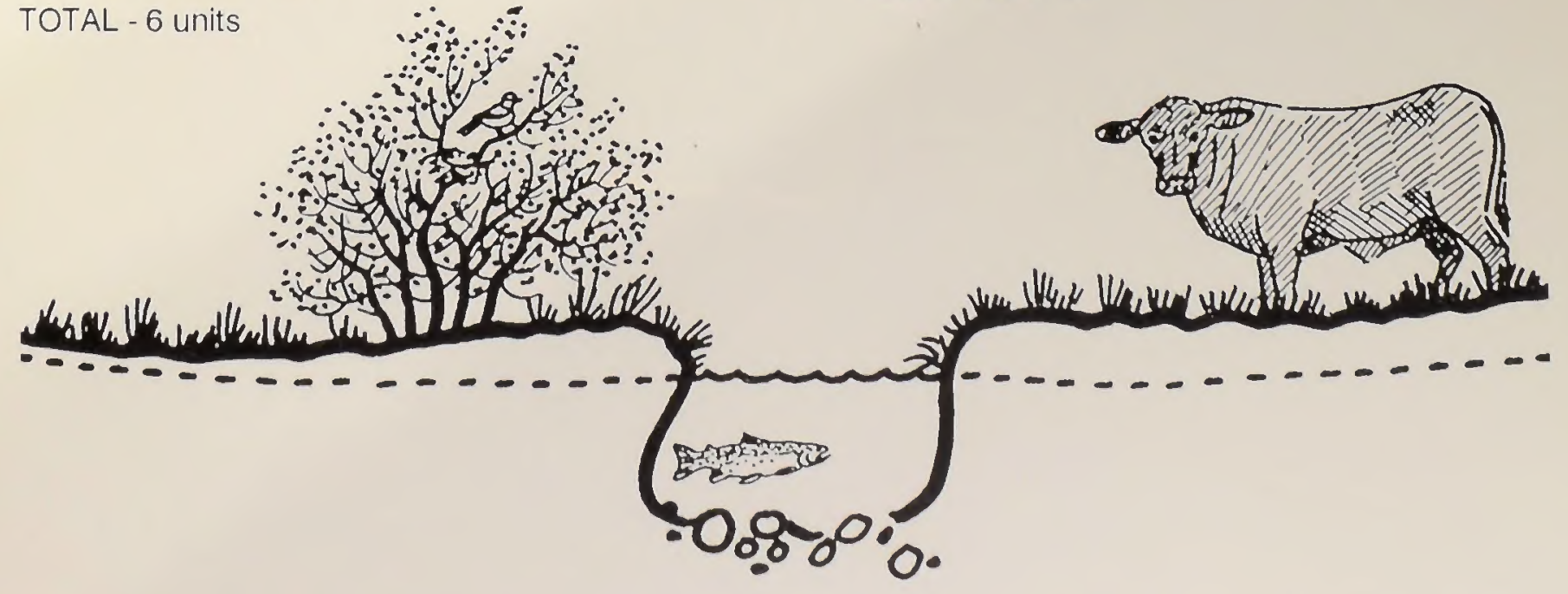

Recovery of Riparian-Wetland Systems can Occur when Careful Grazing Management is Practiced 


\section{FY95-2000 Planned Actions}

\section{Planning}

ALL OFFICES - grazing AMP's - 50 units

CABALLO RA - Sacramento Escarpment HMP

-1 unit

SOCORRO RA - Quemado HMP

TOTAL ACTIVITY PLANS - 52 units

\section{Inventory and Monitoring}

Inventory

ALL OFFICES - intensive riparian inventories 106,600 acres/366 miles

ALL OFFICES - assess non-perennial riparian-wetland needs

\section{Monitoring}

ALL OFFICES - 100 units

Project Development and Maintenance

Development

ALL OFFICES - 85 units

Maintenance

ALL OFFICES - 130 units

Riparian-Wetland Area Acquisitions

ALL OFFICES - 4 units 
Summary of Riparian-Wetland Area Workload and Budget (FY87-2000)

\begin{tabular}{|c|c|c|c|c|c|c|c|c|c|c|}
\hline \multirow{3}{*}{$\begin{array}{l}\text { WORKLOAD } \\
\text { MEASURES }\end{array}$} & \multicolumn{4}{|c|}{ COMPLETED } & \multicolumn{4}{|c|}{ PLANNED * } & & \\
\hline & \multicolumn{2}{|c|}{ FY87-89 } & \multicolumn{2}{|c|}{ FY90 } & \multicolumn{2}{|c|}{ FY91-94 } & \multicolumn{2}{|c|}{ FY95-2000 } & \multicolumn{2}{|c|}{ Total Planned } \\
\hline & Units & Cost & Units & Cost & Units & Cost & Units & Cost & Units & Cost \\
\hline $\begin{array}{l}\text { Inventory } \\
\text { (000's of Acres) }\end{array}$ & 13 & 102 & 91 & 63 & 2 & 500 & 107 & 828 & 109 & 1,328 \\
\hline $\begin{array}{l}\text { Monitoring } \\
\text { (No. of Plans) }\end{array}$ & 27 & 70 & 6 & 25 & 17 & 354 & 100 & 540 & 117 & 894 \\
\hline $\begin{array}{l}\text { Project Development } \\
\text { (No. of Projects) }\end{array}$ & 39 & 205 & 8 & 64 & 73 & 520 & 85 & 956 & 158 & 1,276 \\
\hline $\begin{array}{l}\text { Activity and Land } \\
\text { Use Plans } \\
\text { (No. of Plans) }\end{array}$ & 19 & 120 & 1 & 25 & 46 & 800 & 50 & 1,080 & 96 & 1,880 \\
\hline Maintenance (No.) & 12 & 6 & 3 & 8 & 88 & 276 & 130 & 450 & 218 & 726 \\
\hline Acquisitions (No.) & 3 & - & 4 & - & 3 & - & 4 & - & 7 & - \\
\hline $\begin{array}{l}\text { Total Cost for } \\
\text { Objectives (\$000's) }\end{array}$ & - & 503 & - & 185 & - & 2,450 & - & 3,654 & - & 6,104 \\
\hline
\end{tabular}





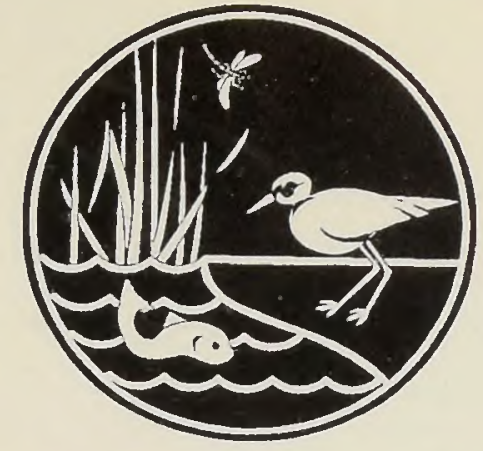

\section{APPENDIX A :}

\section{Legislation, Executive Orders,}

The following laws, regulations, and Executive Orders provide the foundation for management of riparianwetland areas on public lands.

\section{Laws}

Taylor Grazing Act (TGA) of 1934 - Directs the Secretary of the Interior to stop injury to the public lands, including riparian-wetland areas, by preventing overgrazing and soil deterioration and to provide for their orderly use, improvement, and development.

Land and Water Conservation Fund Act of 1964 Establishes a fund to preserve, develop, and assure access to outdoor recreation resources.

National Environmental Policy Act (NEPA) of 1969 Requires Federal agencies to initiate and use ecological information to analyze the planning and development of resource-oriented projects, including those affecting riparian-wetland areas.

Endangered Species Act (ESA) of 1973 - Requires Federal agencies to ensure that proposed actions do not jeopardize the continued existence of a threatened or endangered species or cause its critical habitat to be adversely modified or destroyed.

Federal Land Policy and Management Act (FLPMA) of 1976 - Requires that public lands be managed in a manner that will protect the quality of ecological, environmental, and water resource values, among others, including riparian-wetland areas.

Clean Water Act of 1977 (Federal Water Pollution Control Act) - Provides for the protection, restoration, or improvement of water quality, including riparianwetland areas

Food Security Act of 1985 (Farm Bill) - Provides incentives for riparian-wetland area protection and restoration on farmlands.

Emergency Wetland Resources Act of 1986 Promotes the conservation of riparian-wetland areas by intensifying cooperative efforts among State, private, and Federal interests.

Water Quality Act of 1987 (Amendment to Clean Water Act) - Establishes a program to manage nonpoint source (NPS) pollution.

\section{Executive Orders}

Executive Order 11988 (Floodplain Management) Mandates a reduction in hazards to human safety and preserves values served by floodplains.

Executive Order 11990 (Protection of Wetlands) Minimizes the destruction, loss, or degradation of wetlands.

\section{Policies}

BLM Manual 1731 - Provides guidance for the preservation, protection, and acquisition of riparian-wetland areas, as necessary.

BLM Manual 1737 -Provides guidelines for the protection and acquisition of riparian-wetland areas. as needed, to preserve this habitat type. 
Bureau of Land Management

Riparian Area Management Pollcy

\section{BACKGROUND}

Riparian areas are unique and among the most productive and 1mportant ecosystems, comprising approximately 1 percent of the public lands. Characteristically, riparian areas display a greater diversity of plant, f1sh, widlife, and other andmal species and vegetation structure than adjoinlng ecosystems. Healthy riparian systems filter and purify water as 1 moves through the Ilparlan zone, reduce sediment loads and enbance soll stability, provide micro-climate moderation when contrasted to extremes in adjacent areas, and contribute to groundwater recharge and base flow.

\section{DEFINITIONS}

R1parian Area - an area of land directly influenced by permanent water. It has visible vegetat1on of physlcal characterist1cs reflective of permaneat water 1 af luence. Lake shores and stream banks are typlcal riparlan areas. Excluded are such sites as ephemeral streams or washes that do not exhlb1t the presence of vegetation dependent upon free water in the soll.

Riparian Area-Dependent Resources - resources such as water, vegetat1on, f1sh, and certaln wildife that owe their existence to the riparian area.

\section{OBECTIVE}

The objective of riparian area management 18 to maintaln, restore, or 1mprove riparian values to achleve a healthy and productive ecological condition for maximum long-term benefits.

\section{POLICY STATEMENTS}

In order to meet the foregoing objective, the Bureau will to the extent pract 1cal:

- Achleve riparian area 1mprovement and maintenance objectives through the management of existing uses wherever feasible.

- Ensure that new resource management plans and activity plans, and existing plans when revised, recognlze the importance of riparian values, and inflate managent to mintain, restore, or improve them.

- Prescribe management for riparian values that 18 based upon site-specific characteristics and settings.

- Give special attention to monitoring and evaluating management activit es 1n riparian areas and revise management practices where site-specific objectives are not belng met.

- Cooperate with and encourage the involvement of interested Federal, State, and local governments and private parties to share inforsation, 1mplement managemeat, coordinate activities, and provide education on the value, productivity, and management of riparian areas.

- Retaln riparian areas in public omership unless disposal would be in the public interest, as determined in the land use planning system.

- Identify, encourage, and support research and studies needed to ensure that riparian area management objectives can be properly defined and met.

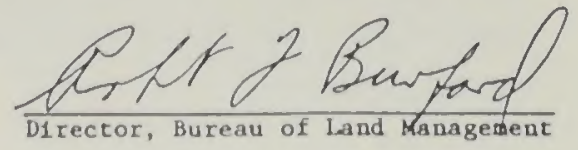




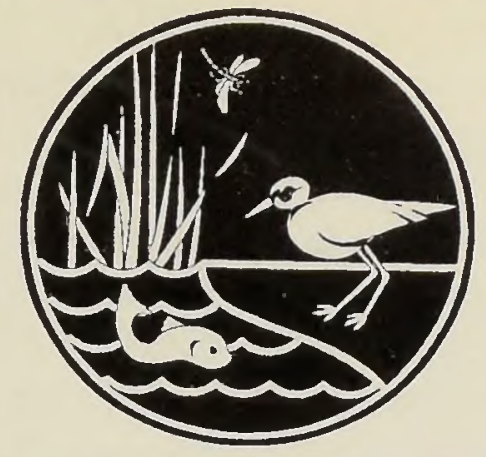

\section{APPENDIX B :}

\section{National and New Mexico}

\section{Resource Program Goals}

\section{National Goals}

At the National level, the Bureau has developed a strategy, entitled Riparian-Wetland Initiative for the 1990's. It provides an overall national strategy to guide the Bureau's riparian-wetland area initiatives. Other plans, such as this document, New Mexico Fish and Wildlife 2000, Range of Vision, and Recreation 2000, provide additional guidance. Following are the National riparian-wetland goals.

- Restore and maintain riparian-wetland areas so that 75 percent are in proper functioning condition by 1997. The overall objective is to achieve an advanced ecological status, except where resource management would require a lower ecological status for such purposes as vegetation diversity.

- Protect riparian-wetland areas and associated uplands through proper land management and avoid or mitigate negative impacts. Acquire and expand key areas to provide for their maximum public use, protection, enhancement, and simplification of management.

- Ensure an aggressive riparian-wetland area information/outreach program, including providing training and research.

- Improve partnerships and cooperative restoration and management processes in implementing the riparian-wetland area initiative.

\section{New Mexico Goals}

The overall goal of BLM New Mexico is to ensure that at least 75 percent of riparian-wetland areas are in good or better ecological condition or are meeting management objectives by the year 2000 .

Section 103 of the Federal Land Policy and Management Act of 1976 (FLPMA) defines "multiple use" as

a combination of balanced and diverse resource uses that takes into account the longterm needs of future generations for renewable and nonrenewable resources, including, but not limited to, recreation, range, timber, minerals, watershed, wildlife and fish, and natural, scenic, scientific, and historical values and harmonious and coordinated management of the various resources without permanent impairment of the productivity of the land and the quality of the environment with consideration being given to the relative values of the resources and not necessarily to the combination of uses that will give the greatest economic return or the greatest unit output." Section 202(c) (2) of FLPMA directs that land use plans "use a systematic interdisciplinary approach to achieve integrated consideration of physical, biological, economic, and other sciences."

We want to ensure that in New Mexico, the integrated, multiple-use directive of FLPMA is carried from the land use plan to specific project implementation in a 
manner that maintains the full spectrum of multipleuse objectives and guidance that have been articulated in higher order planning. In order for this to happen, the activity plan must be bridged to the land use plan. Such a bridge is provided by this document.

The goals and land use plan guidance brought together in this document represent the direction we would like to see activity planning in New Mexico's riparian-wetland areas take between now and the year 2000. It is worth re-emphasizing that the focus of this effort is a land unit, not a specific resource program area. These objectives and guidance are appropriate for all activity planning that encompasses such areas. New Mexico's riparian-wetland areas are not the real $m$ of responsibility of any individual program area; the objectives and guidance demonstrate well that they are the responsibility of all resource program areas. Goals specific to major BLM programs follow:

\section{Rangeland Management}

- Utilize rangeland and riparian-wetland area management prescriptions to help achieve a natural diversity within the desired plant community which is within the capability of the ecological site.

- Give priority to "I" category allotments in developing and revising AMP's and monitoring where riparianwetland area conflicts exist.

- Meet livestock, wildlife, and watershed management objectives on a sustained yield basis through proper grazing practices, rather than by total exclosure, where possible.

- Involve grazing permittees and other affected interests in development of management prescriptions.

\section{Watershed Management}

- Improve conditions in all watersheds containing nonpoint source pollution (NPS) impacted water bodies identified by the State of New Mexico.
- Use best management practices (BMP's) established in site-specific activity plans to sustain or improve riparian-wetland area conditions to comply with the State of New Mexico's Water Quality Standards.

- Control erosion and sediment production from riparian-wetland areas. Increase vegetative cover, stabilize stream banks, control gully erosion, and minimize surface disturbing activities in all riparianwetland areas.

- Obtain the legal protection of water necessary to sustain riparian-wetland areas and their associated uses.

Land Use Planning

- Goals and objectives for riparian-wetland area management are to be addressed and incorporated into all future RMP's.

- On-the-ground implementation of riparian-wetland area management actions must conform (be consistent with) land use planning.

Fish and Wildile Habitat Management

- Manage riparian-wetland areas as contributors to biological diversity on a regional or national scale and maintain or enhance the natural biological diversity present within these ecosystems.

- Manage riparian-wetland areas to maintain special habitat features. Those features include snags and woody debris such as large downed logs. Maintain such vegetation conditions as may be necessary to continue wildlife use of the special habitat features.

- In crucial wildlife areas, such as big game winter range, calving and fawning areas, and bald eagle use areas, maintain vegetation cover along watercourses to provide species habitat requirements. 
- Implement other riparian-wetland area management objectives contained in New Mexico Fish and Wildlife 2000 (BLM 1989).

- Use vegetation management practices to achieve Wildlife Management Program goals for natural habitat diversity.

- Manage riparian-wetland areas to maintain or create high priority habitats for wildlife. Such habitats include calving, fawning, and spawning areas, known cover and shade areas, and known nesting areas for priority species.

\section{Special Status Species Management}

- Manage riparian-wetland areas to protect and promote recovery of listed species that occur in or utilize these ecosystems.

- Manage riparian-wetland areas to maintain populations of plants and animals at a level which will avoid endangering the species or the need to list the species as threatened or endangered by either State or Federal governments.

Recreation Management

- Design recreation management prescriptions for compatibility with riparian-wetland area habitat management goals.

- Consider the scenic, scientific, and educational values of riparian-wetland areas based on the Bureau's visual resource management (VRM) standards.

\section{Forest and Woodland Management}

- Integrate riparian-wetland area management needs in the design of harvest prescriptions to provide for buffer zones of appropriate size to protect these values from adverse impacts created by harvest activities.
- Provide for riparian-wetland buffer zones in the calculation of sustained yield harvest for any forest or woodland area.

Lands and Realty Management

- Consider riparian-wetland area values when evaluating land tracts for acquisition or disposal in land tenure adjustment activities.

\section{Wilderness Area Management}

- Management prescriptions for riparian-wetland areas within wilderness will be in accordance with wilderness management guidelines.

Minerals Management

- Design minerals management prescriptions and special stipulations compatable with riparianwetland habitat management goals.

- Identify and provide for riparian-wetland buffer zones in the exploration for and development of mineral resources.

\section{Fire Management}

- Wildfires will be managed adhering to District fire management plans in accordance with Departmental and Bureau standards.

- Prescribed fire should be utilized to meet resource objectives, where feasible.

\section{Cultural Resource Management}

- Manage cultural resources within riparian-wetland settings to protect and preserve representative samples of the full array of cultural resources on public lands for the benefit of scholarly and public use by present and future generations. 



\section{GLOSSARY OF TERMS}

- A -

Activity Plan - A more detailed and specific plan for management of a single resource program or plan element undertaken as necessary to implement the more general resource management (RMP) decisions.

Allotment Management Plan (AMP) - A document which prescribes the manner in and extent to which livestock grazing is conducted and managed in an allotment to meet multiple-use, sustained yield, economic, and other needs and objectives as determined through land use plans.

Area of Critical Environmental Concern (ACEC) - An area where special attention is required to protect and prevent irreparable damage to important historic, cultural, or scenic values; fish and wildlife resources; or other natural systems or processes or to protect life and safety from natural hazards.

$\cdot B-$

Best Management Practices (BMP's) - Methods, measures, or practices to prevent or reduce water pollution, including, but not limited to, structural and nonstructural controls and operations and maintenance procedures. Usually, BMP's are applied as a system of practices rather than a single practice. BMP's are selected on the basis of site-specific conditions that reflect natural background conditions and political, social, economical, and technical feasibility.

$$
-\mathrm{C}-
$$

Coordinated Resource Management Plan (CRMP) - A comprehensive, multiple-use activity plan prepared utilizing the coordinated resource management planning concept.

$$
\text { - E - }
$$

Ecological Site - A kind of land with a specific potential natural community and specific physical site characteristics, differing from other kinds of land in its ability to produce vegetation and to respond to management. Ecological site is synonymous with range site. 
Ecological Status - The present state of vegetation and soil protection of an ecological site in relation to the potential plant community for the site. Vegetation status is the expression of the relative degree to which the kinds, proportions, and amounts of plants in a community resemble that of the potential plant community. The four ecological status classes correspond to $0-25,25-50,51-75$, or 76-100 percent similarity to the potential plant community and are generally called early seral, mid-seral, late seral, and potential plant community, respectively.

Ecosystem - An interacting natural system including all the component organisms together with the abiotic environment that comprises one functioning whole.

$-\mathrm{G}-$

Goal - The desired state or condition that a resource management policy or program is designed to achieve

$-\mathrm{H}$ -

Habitat Management Plan (HMP) - A written and approved activity plan for a geographical area of public lands which identifies wildlife habitat management actions to be implemented in achieving specific objectives related to resource management plan/management framework plan (RMP/MFP) decisions.

Holistic Watershed Approach - Management of riparian-wetland areas on an entire watershed basis rather than focusing on the narrow or isolated or riparian-wetland zone.

- I -

Integrated Habitat Inventory and Classification System (IHICS) - A Bureauwide system for storing and retrieving terrestrial wildlife inventory data.

\section{$-N \cdot$}

Nonpoint Source (NPS) - A water quality term used for pollutants discharged by natural processes (precipitation, seepage, percolation, and runoff) that are not traceable to any discrete, discernable, or confined conveyance facility.

\section{- P -}

Proper Functioning Condition - When riparian-wetland areas dissipate stream energy associated with high water flows, thereby reducing erosion and improving water quality; filter sediment and aid floodplain development; improve floodplain retention and resulting groundwater recharge; develop root masses that stabilize stream banks against cutting action; provide more productive habitats for aquatic and terrestrial wildlife; and develop diverse stream channel characteristics which provide diverse habitat and lend stability, they are functioning properly. 
$-\mathrm{R}$ -

Resource Management Plan (RMP) - A land-use plan that establishes in a written document the following: land areas for limited, restricted, or exclusive use; allowable resource uses, either singly or in combination; resource condition goals and objectives; program constraints and general management practices (prescriptions); need for an area to be covered by more detailed and specific plans; support actions such as protection, access development, realty, cadastral survey, etc.; general implementation sequences for planned actions; and intervals and standards for monitoring and evaluating the plan.

$-S-$

Seral Stage - One of a series of biotic communities that follows another in time on any given area. 






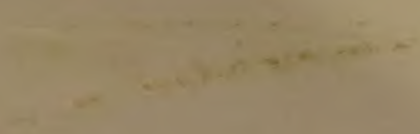

